\title{
ECONOMIC RESTRUCTURING AND RETIREMENT IN URBAN CHINA
}

\author{
John Giles* \\ CRR WP 2008-24 \\ Released: January 2009 \\ Draft Submitted: December 2008 \\ Center for Retirement Research at Boston College \\ Hovey House \\ 140 Commonwealth Avenue \\ Chestnut Hill, MA 02467
}

Tel: 617-552-1762 Fax: 617-552-0191

* John Giles is an associate professor of economics at Michigan State University. The research reported herein was pursuant to a grant from the U.S. Social Security Administration (SSA) funded as part of the Retirement Research Consortium (RRC). The findings and conclusions expressed are solely those of the author and do not represent the views of SSA, any agency of the Federal government, Michigan State University, Boston College, or the RRC. This research was supported by the Steven H. Sandell Grant Program at Center for Retirement Research at Boston College (Sub-award 786-1, prime award 10P-98361-1-03). The author is also grateful for grants to support field research for the 2001 China Urban Labor Survey from Michigan State University (Intramural Research Grants Program), the Chinese Academy of Social Sciences, Ford Foundation (Beijing), the University of Michigan (Rackham Faculty Research Grant), the Australian Research Council, the International Centre for the Study of East Asian Development (ICSEAD), and the World Bank (Beijing), and support for follow-up research from the Weatherhead Center for International Affairs (WCFIA) at Harvard University (Academy Scholars Program) and the W.E. Upjohn Institute for Employment Research.

(C) 2008, by John Giles. All rights reserved. Short sections of text, not to exceed two paragraphs, may be quoted without explicit permission provided that full credit, including (C) notice, is given to the source. 


\begin{abstract}
In its gradual approach to economic transition, China deferred the difficult process of restructuring state owned enterprises (SOEs) until the mid-1990s. When restructuring of large scale SOEs accelerated after 1997, China witnessed sharp declines in the employment of urban residents. While some dislocated state sector workers made a transition to work in the non-state sector, large shares of laid off workers spent long periods unemployed or out of the labor force. Much of the transition out of the state sector occurred through early retirement and exit from the labor force of older workers. While earlier work suggested that the sharp decrease in labor force participation of older women is driven by reappearance of discrimination in the labor market, analysis of reemployment decisions suggests that exit from the labor force reflects a choice. Women exited the labor force in great numbers after 1996, but women with adult children of college age are 60 percent more likely than other women to be re-employed within a year. We also find weak evidence that women who provide care for elderly family members are less likely to be employed. An increase in the labor supply of older women after 2004, however, suggests that the exit of older women from the labor force between 1996 and 2002 was driven primarily by generous early retirement pensions offered during the process of restructuring.
\end{abstract}




\section{Introduction}

Prior to the economic restructuring of the 1990s, employees in China's state and collectively owned urban enterprises benefited from stable employment followed by a retirement with generous pension support. When restructuring of state owned enterprises (SOEs) became a priority after 1996, aggressive implementation of early-retirement for older workers and retrenchment with generous benefits (xiagang) were two mechanisms used to reduce the state sector workforce. Administratively encouraged retirement, however, is not synonymous with a final decision to retire, and many workers, including those over compulsory retirement age for state sector and government units, could be productive in the labor force well into the future. Retirees are not prohibited from returning to work in the private sector, and face no reductions in pensions if they choose to do so.

In this paper, I first review the institutional history of China's labor market during the transition period, and then examine evidence on the labor force participation, unemployment and retirement behavior that occurred as a result of the restructuring of China's state owned and collective owned industries from 1996 onward. From the descriptive statistics presented, it is apparent that older workers, and in particular women over 45, dramatically altered their labor force participation behavior. During economic restructuring, older workers were able to draw pensions in return for early retirement, and despite concerns of pension arrears expressed in the popular press, coverage for early retirees was quite high. A duration analysis of the factors affecting return to employment subsequent to layoff is then presented, and this highlights the importance of both the early retirement pension in creating disincentives to return to work, and the positive incentive effects of having a college-age adult child. The paper then concludes with 
discussion of additional preliminary evidence on women's labor force participation which we observe from the 2004 and 2006 rounds of the China Health and Nutrition Survey (CHNS).

\section{The Labor Market in China's Economic Transition}

The gradual approach to economic transition pursued by China's economic reformers stands in sharp contrast to the economic transition strategies pursued by countries in Eastern and Central Europe and the former Soviet Union. At the outset of reform, normally dated to Deng Xiaoping's political recovery in late 1978, China's leaders were considering neither a transition from central planning nor a dramatic reduction in the role played by the state sector in the economy. In urban areas, the primary objective of reformers during the 1980s was to improve efficiency of the state sector. To this end, managerial decision-making was decentralized, and use of incentives was expanded with introduction of bonuses in 1984, followed by experiments with contracts governing the employment relationship in 1986. ${ }^{1}$ Further, a dual track production system was implemented, which arguably promoted more efficient allocation of resources by allowing enterprises to retain profits on goods produced using market purchased inputs and sold outside the plan.

Entry of non-state firms was viewed positively because new firms reduced bottlenecks in the central planning apparatus. Over the course of the 1980s, output from the non-state sector grew rapidly and non-state firms, primarily township and village enterprises, earned considerable profits by undercutting prices for many goods produced in the state sector. ${ }^{2}$ More rapid growth of the state sector led to a decline in the relative contribution of the state to total output, and, as shown in Figure 1, this continued throughout the 1990s. In spite of the change in sectoral composition of production, however, no real effort was made to shift labor out of the state sector until well into the 1990s. Indeed, as shown in Figure 2, total employment in the state sector continued to grow through 1996. Although a new bankruptcy law was in place by late 1988, there was no commitment to allow loss-making firms to fail or even a willingness to tolerate the

\footnotetext{
${ }^{1}$ The "Resolution on Economic Institutional Reform," passed by the Communist Party in October 1984 introduced a system in which an enterprise's total wage bill varied with firm profitability and facilitated payment of bonuses. The State Council approved “Temporary Regulations on Use of Labor Contracts in State-Run Enterprises” in 1986 (Meng, 2000).

${ }^{2}$ Naughton (1995) coined the expression "growing out of the plan" to describe the gradual decline in the role of the state sector in the face of a more rapidly growing non-state sector.
} 
widespread layoffs which may have encouraged movement of labor to non-state or private sectors. In the wake of the post-Tiananmen retrenchment, there was even considerable uncertainty as to the future of economic reform. Observers of China's political system typically emphasize Deng Xiaoping’s "southern tour” in early 1992 as the signal of renewed commitment to economic reform, and the start of a second phase of China's reform process in which leaders recognized that they were in the process of transitioning to an economy in which the state sector would play a much diminished role.

By the mid-1990s, competition from the non-state sector had eroded state sector profitability to the point where SOE losses were clearly unsustainable, and it was clear that the combination of soft budget constraints and the government's full employment goals had led to substantial redundant labor in SOEs (Dong and Putterman, 2001 and 2003; Li and Xu, 2001). The government moved forward with extensive enterprise restructuring as accumulating financial losses threatened the solvency of the state-controlled financial system (Lardy, 1998). Restructuring began in 1994 with an emphasis on privatizing small and medium-sized SOEs while continuing to support larger enterprises, or "seizing the large and letting go of the small" (zhuada fangxiao) (Cao, Qian and Weingast, 1999).

With the passage of the Company Law in 1997, reform in ownership of larger SOEs proceeded quickly. The objective was to shift all enterprises to modern forms of corporate governance that defined shareholders and boards of governors, shut down unprofitable enterprises, and diversified ownership. Further, another direct link between enterprises and workers was broken with acceleration of housing privatization in 1998. The restructuring that followed passage of the Company Law is evident in the sharp drop in employment in SOEs and Collectives after 1997 (Figure 2). As in the transition economies of Eastern and Central Europe and the former Soviet Union, restructuring led to widespread labor dislocation in urban China.

The delayed start of restructuring appears rational ex post. Additional time made it easier to shift large numbers of older and less skilled workers into actual or de facto early retirement, and from 1992 onward, young entrants into the labor force knew not plan for long-term employment in the state sector. Changes in how pensions, housing and health insurance were provided could be phased in gradually, and this likely reduced in severity the dislocation experienced by the urban labor force. 
To be sure, delay in the start of restructuring and continued extension of soft credit to large SOEs put considerable strain on the financial system in the late 1990s, but economic growth and the reasonably successful operation of the piecemeal safety net have worked together to cushion the blow. Still, the growing private sector only absorbed a fraction of displaced workers, as evident in Figures 2 and 3, but relatively generous early retirement packages and unemployment and displaced worker benefits of long duration may have created disincentives for older and less skilled workers to reenter the labor force.

Also evident in Figures 2 and 3, is a rapidly growing category of workers labeled as "other" that reflects, in part, the unique role that an informal sector plays in the new labor market. By 2002, nearly 40 percent of the urban workforce fell into a category comprised of unreported urban resident workers and undocumented employment of migrants in urban areas. To some extent, the increase in this category may lead us to overstate the decline in state sector employment if some state sector firms are employing workers informally and not making social welfare contributions. ${ }^{3}$ Cai et al (2006) hypothesize and provide some evidence that a significant share of this category may be comprised of migrants. China's large migrant labor force, estimated at over 100 million individuals, plays a significant role in the urban labor market, and may be placing considerable downward pressure on wages of displaced workers in the informal sector where they compete directly for employment.

Below we will first present evidence on retirement, unemployment, labor force participation in urban China. Next, in section 3 we first discuss social safety nets in China and provide evidence on coverage for involuntarily laid off workers. We next examine the determinants of whether individuals who have lost employment during restructuring are reemployed. Central to this effort is a focus on the disincentive effect of early retirement pensions and the demographic characteristics of adult children.

\section{Evidence on Unemployment and Labor Force Participation}

With China's economic restructuring, unemployment jumped sharply and labor force participation fell, yet these changes are not reflected in China's official labor force statistics.

\footnotetext{
${ }^{3}$ Official statistics on employment come from two statistical surveys. One is the Comprehensive Labor Statistics Reporting System (CLSRS), which collects information on urban employment by all independent accounting units, and the other is the Sample Survey on Population Changes (SSPC), which covers the entire population. The difference between the larger urban employment number from the SSPC and the smaller from the CLSR comprise the "other" category.
} 
Official statistics and many estimates of unemployment constructed by both Chinese and foreign researchers are drawn from administrative information on workers officially receiving registered unemployment benefits. The low estimate of China's urban unemployment rate is typically calculated as the share of legal urban residents who are registered as unemployed. This share of individuals with access to unemployment insurance benefits is reported in the fifth column of Table 1.

Other efforts to come up with a more accurate unemployment rate have involved adding administrative information on laid-off workers from the state sector (known as xiagang workers) to those who are registered unemployed, and then, in some cases, performing some adjustments to official data. In principle, the unemployed should include all jobless individuals who are able to work and are currently searching for work. Thus, estimates based on administrative data are subject to three obvious short-comings: first, substantial numbers of officially laid off or registered unemployed workers may actually be working part- or full-time or may no longer be looking for work (and thus out of the labor force). Second, official numbers exclude large numbers of unemployed without official status as unemployed. Finally, no account is made for rural laborers living and working in China's cities.

As seen in Table 2, there exist a wide range of alternative estimates, even for the same year. In 1997, for example, estimates of the unemployment rate ranged from 5.5 to 14 percent. There are also differences in the estimates of trends over time. Unemployment rates estimated from three surveys shown in Table 2, in rows (11) through (13), use standard ILO definitions of labor force participation and unemployment, and show a sharp increase in unemployment after restructuring got underway in 1997. Indeed, in row (11) GPZ estimates that unemployment among registered urban residents rose to 11.1 percent by 2002, and as of 2004, the IPLE04 survey (row 13) suggests that the unemployment rate among urban residents was still 9.9 percent. In spite of the rapid growth of China's economy and exit from the labor force of many older workers, unemployment in urban China remains quite high.

It is also notable that the estimated urban unemployment rate falls considerably from 11.1 to 7.3 percent in 2002 once migrants are included in estimation. Media reports of poor unemployed migrants in China's cities notwithstanding, most migrants cannot afford to be 
unemployed for long periods of time. When they are faced with the prospect of long-term unemployment, migrants leave the city and return to home villages.

High unemployment rates do not necessarily reflect deprivation. Workers with support from xiagang or registered unemployment subsidies may have very high reservation wages and spend considerable time waiting to find the appropriate job. Dislocation becomes a more serious problem if it leads families into poverty. Ravallion and Chen (2005), among others, have emphasized low overall incidence of poverty in urban areas, but recognize that pockets of poverty may still be quite severe where dislocated workers are found in high concentration.

In cities with resource extractive industry, dislocation is strongly correlated with poverty. Cities with resource extractive industries that were exhausted and heavy industry that had previously made use of the local resource base were hit particularly hard. Estimates of unemployment rates based on the 2000 Census (which use a non-standard definition of labor force participation) suggest an unemployment rate of 8.9 percent in cities without resource extractive industries, but 10.6 percent in resource-based cities. In those cities suffering resource exhaustion, unemployment rates reached 15.5 percent even with considerably lower rates of labor force participation. ${ }^{4}$ Table 3 breaks down a national urban poverty rate of 5.1 percent for 2002 by region, and by presence of resource extractive industries. In general, the relatively high unemployment rates in China's cities do not necessarily translate to high incidence of poverty, but poverty rates are considerably higher where resource extraction industries are concentrated, and in the five cities of the northeast where the primary resource was exhausted the poverty rate approached 17 percent. $^{5}$

Retirement Behavior in Urban China: Comparisons of Unemployment and Labor Force Participation across Demographic Categories

Comparisons across demographic groups provide important patterns behind reported unemployment and labor force participation rates. Several surveys conducted from 1999 onward suggest the following observations:

\footnotetext{
${ }^{4}$ See Cai and Wu (2005) for additional details.

${ }^{5}$ In the past, workers also obtained subsidized housing in areas where they were registered residents and state sector employees. With housing reform, workers typically purchased their apartments at deeply discounted prices. Included in the cost of moving to a new location is the cost of finding new housing.
} 
- Labor force participation for men and women under age 30 is quite low, even as unemployment rates for this group are particularly high.

- The effects of early retirement programs are evident in the drop in labor force participation of men after age 50 and women after age 45 . Some of this drop may be attributable to layoff, rather than retirement of older workers.

- Some workers seek to reenter the labor force in occupations where age restrictions created by mandatory retirement ages are non-binding. In spite of mandatory retirement at 55 for women and 60 for men, over ten percent of men and women are in the labor force in the five years after mandatory retirement.

Table 4 presents summary statistics reflecting these basic characteristics of unemployment and labor force participation using the 2002 MOLSS and the 2004 SPS surveys. ${ }^{6}$ Given differences in coverage of these two surveys, it is not appropriate to make comparisons over time, but patterns within each survey are quite similar. Unemployment rates for men and women under age 30 are quite high, though labor force participation is fairly low (presumably because some young adults may still be in college). Labor force participation for men falls from over 80 percent for cohorts in the 45 to 50 age range, to roughly 68 percent for the 50 to 55 cohort to 44 percent for the cohort within five years of mandatory retirement age. For women, the sharp drop in labor force participation starts roughly five years earlier. Women's labor force participation falls by 15 percent as we move from the 40 to 45 to the 45 to 50 cohort, to only 25 percent for women in the five years before retirement. ${ }^{7}$

Declines in labor force participation with age may reflect disproportionate dislocation of women during state sector restructuring, and suggest that the process of transition may have reintroduced gender biases in employment (e.g., Maurer-Fazio and Hughes, 2002; and MaurerFazio and Rawski, 1999). Alternatively, growth in urban household incomes and the relative success in meeting pension obligations for the early-retired may have led older women to exit the labor force to care for elderly family members or for grandchildren. In our analyses below,

\footnotetext{
${ }^{6}$ Giles, Park and Cai (2006) present a consistent set of descriptive statistics using the 2001 CULS, and the 1999 and 2002 waves of the China Income Project (CHIPS) apparently show similar trends.

${ }^{7}$ Note that the apparent increase in unemployment rates between 2002 and 2004 appear to be driven by a rise in labor force participation by some demographic groups, particularly women. Lack of comparable coverage may be driving this result, or alternatively, the improving economy after 2002 may have drawn more workers back into the labor force by 2004.
} 
extended family demographic characteristics are important for explaining the return to employment. While such a finding does not rule out discrimination in hiring within the private sector, it does suggest that part of the decline in labor force participation and early retirement behavior of older workers is driven by labor supply decisions, thus suggesting that one important transition from the state sector was transition out of the labor force.

The share of the work-force who were xiagang, registered unemployed and retired is shown in Tables 5 and 6 for respondents to the 2002 MOLSS 66-City survey and the 2004 14-City SPS, respectively. In order to provide a sense of how well these support mechanisms are functioning and rough effect on employment outcomes, we also show shares of workers in each of these categories who were receiving benefits and currently employed.

In the SPS, 7.8 percent of the surveyed adults report current xiagang status, which is a somewhat lower share than the 8.8 percent of adults interviewed in the MOLSS survey conducted in 2002. Further, the share of xiagang workers reporting that they received benefits fell considerably to 8.6 percent in the 2004 survey, from 28 percent in the 2002 survey. Given that the xiagang program was supposed to have been phased out by the end of 2002, it is likely that many respondents mistakenly referred to themselves as currently xiagang, rather than ever xiagang. The higher rate of employment among xiagang workers in the 2004 SPS than the 2002 MOLSS survey is also consistent with workers confounding historical experience with current status.

Comparing the registered unemployment rate in the SPS survey (Table 6) with the rate shown in the MOLSS survey (Table 5) would seem to indicate that the broader program for providing insurance to unemployed workers is becoming more complete. Further, the share of registered unemployed receiving benefits is higher in the later survey, suggesting that gains have been made in the implementation of the program. Still, a considerable share of workers with registered unemployed status, are nevertheless engaged in some type of wage-earning activity.

Finally, workers who have retired early, normally receive pensions. The great majority of early retirees who are within ten years of mandatory retirement ages of 55 for women and 60 for men are receiving pension benefits. Substantial shares of retirees do return to the labor force, but they also have the cushion of pensions with high replacement rates indexed to inflation. 
In analyses of non-working duration and exit from the workforce below, uneven coverage afforded to laid-off workers both within and across ownership structures is useful for analyzing the impact of unemployment benefits on the reemployment of urban workers in China. We use the earlier China Urban Labor Survey (CULS), conducted in late 2001, because it carefully recorded work-histories of all individuals and the retrospective window that it provides spans the period during which both the xiagang and registered unemployment mechanisms were introduced. Figure 5 shows the share of working age adults in different demographic groups that were dislocated and out of work between January 1993 and November 2001. It further divides the share of dislocated, out-of-work individuals into three categories: the share with access to xiagang subsidies or unemployment insurance (shaded in gray); the share receiving pension payments (white); and the share lacking access to public support (black). The figure reveals that large fractions of younger and middle-aged workers lacked access to public benefits, that dislocated younger workers were much less likely to have access to public benefits than older workers, and that among middle-aged workers, women were much less likely than men to receive benefits.

In Table 7, we report the total number of involuntary non-working spells for men and women from each sector and the share of workers within each broad ownership sector eligible for different sources of support. Overall, workers previously employed in state sector firms (including majority state-owned firms) and collective sector firms were far more likely to have some source of support. Nonetheless, substantial shares of workers leaving state and collective sector firms still lacked access to xiagang benefits, unemployment insurance or pension support.

\section{The Decision to "Retire" or Reenter the Workforce after Dislocation}

Because extended periods of unemployment can be very costly to workers and their families and in aggregate can have a pronounced effect on macroeconomic outcomes, labor economists have had a longstanding interest in understanding the factors that determine the length of individual unemployment spells. Most early studies of unemployment duration use micro-data from the U.S. and focus on whether specific features of unemployment insurance programs create disincentives to search for new work. U.S.-based research confirms significant disincentive effects of increasing both the duration and level of unemployment benefits. More recently, the impact of benefits on unemployment duration has received renewed attention in 
transition economies as governments have struggled to balance strong political pressure to provide generous safety nets to dislocated state-sector workers with the desire to speed structural adjustment and avoid costly welfare programs. Surprisingly, recent studies of unemployment duration in Eastern European transition economies have not found strong evidence of a disincentive effect of unemployment insurance.

One explanation for lower work responsiveness to unemployment benefits (or other incentives) is that institutional factors impede the process of job search in transition economies. Formal institutions supporting job search (e.g., public and private employment centers, temporary employment agencies) may be nonexistent or under-developed. If they do exist, they are frequently new, unfamiliar, inconvenient, or ineffective. Moreover, individuals who previously had one government-assigned lifetime job are unfamiliar with the process of job search and may be isolated from information about job opportunities, creating “disorganization” that slows adjustment (Blanchard and Kremer, 1997).

The analysis of duration presented here examines the role of information and incentives on unemployment duration by taking advantage of unique features of the CULS. The CULS enumerated work histories, and asked detailed questions about non-employment spells, access to public subsidies, family members (both household members and non-members), family social networks, and the neighborhood in which the household is located. The empirical analysis focuses on estimating how reemployment hazard rates are affected by public subsidies and private incentives (especially those related to family demographics), and access to social networks and other information sources. We focus particular attention on the number of relatives living in the same city as a preferred exogenous measure of a worker's social network. We also examine the effect of neighborhood-based job referral services.

The Chinese context affords several advantages in identifying the effects of information and incentives on the probability of workers' reemployment. Benefit coverage for unemployed urban workers was highly uneven due to failures in the public financing of benefits, providing plausibly exogenous variation in benefit coverage. Most urban Chinese live in housing units originally provided by their employers and the mobility of urban residents in China remains limited, reducing the self-selection of individuals into specific neighborhoods. Finally, previous 
studies of the reemployment of urban workers in China use survey data that are unlikely to be representative.

According to the CULS, 18.5 percent of working-age men and 26.4 percent of working-age women surveyed reported experiencing at least one involuntary job separation. ${ }^{8}$ China's dislocated workers must consider a number of factors when deciding whether and how to search for a new job. New public programs provide subsidies to the unemployed, but they have had highly incomplete coverage and benefits have been subject to frequent revision. There is concern that vulnerable groups such as women, the less educated and older workers may have had great difficulty finding jobs. For workers leaving the state sector, available new jobs may be much more demanding for similar or lower pay than previous jobs, or lack comparable social status. Before reforms, China had one of the highest female labor force participation rates in the world. Like many other transition economies (Svejnar, 1999; Ham et al., 1999), China has since witnessed a marked reduction in labor force participation, particularly for women. For some women, the returns to home production (e.g., childcare or eldercare) may have become more attractive when compared to realistic employment opportunities. On the other hand, the combination of credit constraints and the rapidly increasing costs of educating children and purchasing homes during the period under study may have increased the desire of households to earn additional income.

Below we first introduce an empirical hazard model and specific variables used in our empirical analyses, and then present estimation results. A more detailed presentation including a search theoretic model motivating our empirical tests can be found in Giles, Cai and Park (2005).

\section{Empirical Model}

We first present Kaplan-Meier non-parametric estimates of non-employment survival functions for dislocated male and female workers, broken down by educational attainment, age category, access to unemployment insurance, and the size of family networks. These estimates are descriptive and help motivate the multivariate analysis of reemployment rates.

Our primary tool for analyzing reemployment rates is the discrete time hazard model (Kalbfleisch and Prentice, 1980; Lancaster, 1990). The transition probability or hazard rate,

\footnotetext{
${ }^{8}$ Similar levels of dislocation are also evident in both the 66-City MOLSS survey and in 14-City SPS.
} 
$\lambda(\mathbf{t}, \mathbf{Z})$, is the probability of leaving a state in period $t$ conditional on continuous presence in the state for the previous $t-1$ periods, and a set of covariates, $\mathbf{Z}$. In the most general form of our model, the covariate vector, $\mathbf{Z}$, varies by individual $i$, in neighborhood $j$, in city $k$, at time $t$. The hazard rate, $\lambda\left(\mathbf{t}, \mathbf{Z}_{i j k t}\right)$ is modeled as a logit function:

$$
\lambda\left(\mathbf{t}, \mathbf{Z}_{i j k t}\right)=\frac{\exp \left(\boldsymbol{\alpha}_{t}+\mathbf{Z}_{i j k t} \Pi\right)}{1+\exp \left(\boldsymbol{\alpha}_{t}+\mathbf{Z}_{i j k t} \Pi\right)}
$$

The logit specification allows for time-varying covariates and a flexible form for the effect of time on the likelihood of reemployment in the next period, which has made it particularly attractive for analyzing the duration of welfare spells in the US. ${ }^{9}$ The vector $\boldsymbol{\alpha}_{t}$ consists of indicator variables for length of non-working spell for each of the first six months after separation, and a quartic term in months for months 7 through $96 .{ }^{10}$ The combined time dummies and quartic terms provide a non-parametric control for the duration properties of the model. Exit probabilities are scaled up or down by time-varying covariates, $\mathbf{Z}_{i j k t}$. The general, and most inclusive, specification for $\mathbf{Z}_{i j k t}$ is:

$$
\mathbf{Z}_{i j k t} \Pi=\mathbf{X}_{i j k t} \gamma_{1}+\mathbf{B}_{i j k t}^{\prime} \gamma_{2}+\mathbf{S}_{i j k t}^{\prime} \gamma_{3}+\left(\mathbf{B}_{i j k t} \otimes \mathbf{S}_{i j k t}\right)^{\prime} \gamma_{4}+\mathbf{c i t y}_{k}+\mathbf{y e a r}_{t}
$$

where $\mathbf{X}_{i j k t}$ is a vector of individual worker characteristics and other controls for factors affecting labor demand and supply, $\mathbf{B}_{i j k t}$ contains variables capturing the benefits of nonemployment, $\mathbf{S}_{i j k t}$ contains variables measuring access to information (parameter $s$ in the model), and $\mathbf{B}_{i j k t} \otimes \mathbf{S}_{i j k t}$ denotes the interactions of the variables in $\mathbf{B}_{i j k t}$ and $\mathbf{S}_{i j k t}$.

\section{Variables}

In this section, we define the specific variables used in the empirical estimation. We include a set of variables $\left(\mathbf{X}_{i j k t}\right)$ to control for the effect of individual characteristics and other key labor demand and supply factors. Even though some factors affecting labor supply determine the benefits of non-employment, many individual characteristics, such as human capital, affect

\footnotetext{
${ }^{9}$ See, for example, Bane and Ellwood (1983), Blank and Ruggles (1996), Ellwood (1986), Hoynes (2000), and Hoynes and McCurdy (1994), and Klerman and Haider (2004).

${ }^{10}$ The quartic term is $\left(t+t^{2}+t^{3}+t^{4}\right)(6<t<97)$.
} 
both labor supply and demand at the same time. Such variables are therefore excluded from $\mathbf{B}_{i j k t}$ but are instead given a reduced form interpretation as variables in $\mathbf{X}_{i j k t}$. The impact of these variables on reemployment rates is of independent interest for understanding which types of individuals are able to find new jobs. They include years of schooling, prior work experience, and dummy variables for prior ownership sector of employment which proxy for unobserved characteristics of workers influencing selection into different ownership sectors. ${ }^{11}$

$\mathbf{X}_{i j k t}$ also includes controls for demand shocks. Two time-varying variables control for cityindustrial sector labor demand characteristics that may affect reemployment probabilities. We use annual information from 1995 to 2001 from the China Labor Statistical Yearbook (various years) on employment by industry sector in the five provinces in which our cities are located to control for local labor demand conditions. Annual changes in provincial log state-owned enterprise employment in the industry sector of a worker's prior employment is used to capture the effects of annual labor demand shocks driven by state sector restructuring, and annual changes in log industry sector of employment for all other ownership categories is used control for changing labor demand conditions in the non-state sector. There are 17 broad industry sector categories into which workers are classified based on their prior sector of employment.

Finally, we include two sets of neighborhood variables to control for neighborhood-specific labor demand and supply conditions. The first are measures averaged across all other households surveyed in larger neighborhood clusters (jiedao), and include the log of average per capita nondurable neighborhood consumption and time-varying measures of the non-working share of working-age adults. ${ }^{12}$ The second set of neighborhood terms are variables from the residents' committee (shequ) survey, and include average distance to services (e.g., hospitals, police stations, pharmacies, train station), measures of neighborhood size, and housing characteristics.

$\mathbf{B}_{i j k t}$, the benefits of non-employment, includes variables that indicate whether or not the dislocated worker had access to publicly provided benefits during the period, and a set of variables describing household and family demographics. The main public benefit variable is a time-varying dummy variable indicating whether the individual had potential access to xiagang

\footnotetext{
${ }^{11}$ Unobserved characteristics related to the ownership sector of prior employment, such as differences in workers across sectors in work habits or experience, motivation, or access to information about employment in other ownership sectors may also drive reemployment rates.

${ }^{12}$ In each street office (jiedao) administrative area, we survey an average of three RCs and ten households per RC.
} 
subsidies or registered unemployment benefits. This is the main variable of interest in examining the incentive effects of unemployment subsidy payments. We also include an indicator variable for whether the individual receives a pension from early retirement. Since receipt of a pension is not contingent on employment status, it is equivalent to a wealth or income effect. Both public benefit variables indicate whether a person receives benefits but do not reflect the level of those benefits. We do not include the level of benefits out of awareness that information on benefit levels may introduce endogeneity bias. Receiving benefits is salient in the minds of respondents, while the exact value of benefits is likely to be recalled with error. More importantly, the level of benefits and accuracy of recall are both likely to be correlated with unobserved ability. In China, the level of registered unemployment subsidies, early retirement pensions, and xiagang subsidies are calculated based on prior income levels, years of employment, and unobserved dimensions of status in the firm. Thus, all things equal, a worker with a higher subsidy is likely to be of higher ability, creating an upward bias in the measured effect of subsidies on reemployment, which could offset the expected negative disincentive effect of benefits on reemployment. Such bias provides a possible explanation for Appleton et al's (2002) failure to find an effect of the level of benefits on reemployment probabilities in China. Access to benefits, on the other hand, is likely to be relatively exogenous after conditioning on age (potential experience), education and prior ownership sector. Employers are obligated to provide benefits to all dislocated workers. Local governments are unlikely to exclude low ability workers who have bleaker reemployment prospects and are more likely to slip into poverty in the absence of benefits.

To examine the impact of household and family demographics on labor supply, we include two types of demographic variables: those that describe the composition of the household, and those that describe the number of adult children regardless of whether they are household members. The former include household size, marital status, number of resident children under 6, number of resident children between 6 and 12 years of age, number of resident children between 12 years and 18, number of resident retirees over mandatory retirement age but under 65 , and the number of resident elderly over age 65. The latter include dummy variables for whether the respondent has children between 18 to 23, children between 23 and 28, and children over 28. 
The vector $\mathbf{S}_{i j k t}$ includes variables that measure access to job information and social network effects. The CULS contains information on the age, gender, education, and residence location of different types of non-resident family members, including parents, children, siblings, and cousins. Under the assumption that the number of relatives is not affected by job search strategies, these data can be used to construct a variety of plausibly exogenous social network variables based on kin relationships. In our analyses, we use the number of own generation relatives (siblings and cousins) and the number of spouses' own generation relatives living in the city as preferred measures of social networks. On average, dislocated men and women had 3.75 and 4.06 own generation relatives living in the same city, and the spouses of dislocated men and women had 3.17 and 3.39 own-generation relatives, respectively. We also looked at the effect of having non-resident parents, aunts or uncles living in the city, but these variables never entered significantly and their inclusion did not affect any of the other estimates. We thus exclude them for sake of parsimony.

Correlations between social network size and reemployment probabilities could occur through channels other than job search. For example, if prosperous families are larger and high ability individuals tend to come from or marry into prosperous families, then social network size could be correlated with unobserved ability. While it is not possible to test directly whether unobserved ability is confounded with family size, we do find that the relationship between network size and years of schooling is not statistically significantly. Second, in addition to providing information about job opportunities, the social network might act as an insurance mechanism capable of transferring resources to members suffering from negative shocks, such as unemployment spells. However, descriptive information from the CULS provided in Giles, Park and Cai (2006a) suggests that very few households relied significantly on extended family support to cover living expenses after losing a job. ${ }^{13}$

Some of the previous literature suggests that neighborhood characteristics (e.g., population, mean education and income levels) could also be interpreted as social network variables, but we are concerned that such variables also reflect local labor supply and demand factors, and thus treat them as controls (in $\mathbf{X}_{i j k t}$ ) rather than information variables. The only exception, and our

\footnotetext{
${ }^{13}$ Only two percent of laid-off respondents in the CULS report that assistance from non-resident family members was their most important source of support while out of work (See Table 9 in Giles, Park and Cai, 2006a).
} 
only variable that reflects formal institutions facilitating job search, is an indicator variable for whether the local residents’ committee provided employment referral services.

We also control for city and year effects, where city $_{\mathbf{k}}$ are a set of dummy variables to control for city-wide effects, and year $_{\mathbf{t}}$ are dummies that control for annual macroeconomic shocks.

\section{Identification}

The main identification concern is potential bias from unobserved heterogeneity. The U.S. welfare duration literature (e.g., Hoynes, 2000) pays considerable attention to the problem of endogenous migration. In our study, for example, workers more eager to work might migrate into communities with an employment referral center. This is less of a concern in the Chinese context because moves to a new neighborhood are extremely costly for families facing lost income from a lay-off. Unemployed workers would need to abandon housing that is either still subsidized or was acquired at a bargain price during housing privatization, often with regulations preventing resale, and then move into apartments that are rented or sold at much higher market prices. Migration into cities where one has a large family network is also unlikely for long-term legal urban residents. Legal urban residents who have completed school and who have some work experience stand in sharp contrast to rural migrants in that they are not very mobile. When examining the residence histories of laid off urban residents in the CULS, we find that less than one percent moved into their current city after residence subsequent to layoff. For this reason, we are not concerned about endogenous sorting into cities.

Despite our care in restricting ourselves to plausibly exogenous regressors, it is difficult to rule out the possibility that independent variables are correlated with unobservable individual characteristics that influence reemployment prospects. In our study, for example, we may be concerned that high ability individuals have larger kin networks, or that employee referral centers respond to local labor demand. This is typical of the unemployment duration literature and to a large extent unavoidable given that much of the variation of interest (e.g., in benefit access, social networks, and family demographics) is inherently cross-sectional. To address these concerns, we exploit the rich detail of the CULS to include a large set of control variables that address the most plausible sources of omitted variable bias. For example, we control for past ownership sector of employment (to deal with selection effects), region-specific demand-shocks, 
and a host of neighborhood characteristics. In addition, we regress potentially endogenous regressors on the set of independent variables used in the regressions to check the extent to which they are correlated with observable measures of ability, especially years of schooling, and features of the local labor market. We find no obvious correlation between network variables and observable proxies for ability.

\section{Results}

In Figures 6, 7, 8 and 9, we present non-parametric Kaplan-Meier (1958) survivor functions for different sub-categories of workers experiencing involuntary job loss. In Figure 6, we observe that younger cohorts of dislocated workers tend to find employment faster than older cohorts, and Figure 7 suggests that the more educated among dislocated workers find new employment more quickly. It is notable that men and women with some post-secondary education do not appear to differ as much in the rate of reemployment as men and women with lower levels of education. Figure 8 presents the survivor functions for men and women broken down into three categories of access to formal support. Workers in early retirement typically are older and have secure access to pensions, which are usually more generous than unemployment subsidies and are paid for the rest of a worker's life. Not surprisingly, these workers are the least likely to be re-employed. Second, xiagang and registered unemployed workers have access to less generous, finite benefits, and they exit the non-working state more quickly than early retired workers. Finally, workers without access to formal support find employment faster than early-retired or registered unemployed workers. As is evident from Figure 5, age and access to formal support appear to be highly correlated, and thus identifying any disincentive effect apparent in Figure 8 requires multivariate analyses. Finally, Figure 9 shows survivor functions by number of own generation relatives residing in the city. Workers with larger numbers of own generation family members living in the same city are reemployed faster than workers with smaller social networks.

In estimating the logit hazard model of (3) and (4), we regress a dummy variable for whether a worker is reemployed in the next period on time dummy variables and quartic terms, and different sets of variables that we expect to shift the reemployment hazard rate. In all models we show robust standard errors that are cluster corrected by large neighborhoods (jiedao).

We begin with the stripped down model, in which $\mathbf{Z}_{i j k t} \Pi$ is: 


$$
\mathbf{Z}_{i j k t} \Pi=\mathbf{X}_{i j k t} \gamma_{4}+\text { city }_{k}+\text { year }_{t}
$$

In this base specification, we first look at factors influencing reemployment rates before considering the impact of benefits and access to information.

Often it is difficult to interpret logit coefficients, or even the economic significance of marginal effects. In order to grasp both the economic and statistical significance of our results, we calculate the effects of ceteris paribus changes in variables on one year reemployment rates. For each model, we calculate a baseline monthly hazard rate using an assumed base set of values for all variables, and then convert it to an annual hazard rate. We next calculate the twelve-month marginal effect of specific changes in the variables shown in each table, and divide the twelvemonth marginal effect by the baseline reemployment rate in order to measure the economic significance of marginal changes in important variables.

Age, Education, and Prior Sector of Employment. Results for our simplest specification (columns 1 and 3, Table 8) as well as those including a richer set of covariates, confirm that reemployment probabilities are significantly higher for laid-off workers with more education. An increase in years of education from 12 to 13 years leads to 5.6 and 12.5 percent increases in the probability that men and women will be reemployed within a year. Age is negatively related to the probability of reemployment. Increasing age from 40 to 41 leads to a 4.9 percent reduction in the reemployment rate for men, and a 7.0 percent fall in the reemployment rate for women. Thus, the reemployment prospects of women are more sensitive to both education and age than men.

Columns (2) and (4) of Table 8 add local annual employment shocks to industry sectors of prior employment, and dummy variables for ownership sector of prior employment. A five percent negative change in log SOE employment in a worker's prior industry sector is associated with a statistically significant 1.4 percent reduction in the reemployment probability of men. Given that annual negative shocks to employment during the restructuring period were well over 20 percent in some industry sectors, these demand effects were quite severe for men. We do not find evidence that similar labor demand shocks have the same impact on the reemployment rates of women.

Among the controls in our base specification, we also include several neighborhood variables. Log mean consumption per capita is positively associated with the rate of 
reemployment, and this effect is statistically significant at the 10 percent significance level. Wealthier communities are likely to have higher local demand for service workers, and so laid off workers may find local alternative employment with greater ease. Alternatively, families that have sorted into wealthier neighborhoods may differ both in preferences for leisure and consumption, and in unobserved dimensions of ability that correlate with the ability to find new employment. Other proxies for "neighborhood effects" carry expected signs, but none are statistically significant. The local share of working-age adults not working is negatively associated with reemployment, consistent with a networking story (Calvo-Armengol and Jackson, 2004). The average education level of individuals in the community, and the share of neighborhood households living in homes originally built for private purchase (commodity housing) are both positively associated with reemployment. The magnitudes of these neighborhood effects, however, suggest that they do not have an economically significant effect on reemployment rates.

Public Subsidies, Family Demographics, and Access to Information. To our base specification shown in Table 8, we now consider in Table 9 the logit hazard model specification with a full set of $\mathbf{B}$ and $\mathbf{S}$ variables, including dummy variables for access to unemployment benefits and pensions, household and family demographic characteristics, and measures of access to information. In alternate specifications, $\mathbf{S}$ includes the number of own generation relatives and the presence of local employment referral services. We find that the ability to receive unemployment subsidies (either a xiagang subsidy or unemployment insurance payment) lowers the probability that a man will be reemployed within a year by 34 percent (column 1), but has no significant impact on the reemployment rate of women. The large disincentive effect contrasts with the findings of Appleton et al. (2002) for China, and with a number of studies of other transition countries (Svejnar, 1999). The lack of a statistically significant incentive effect for women is consistent with findings from the Czech Republic (Ham et al, 1999).

In both sets of models we include a set of regressors characterizing household demographic structure. While not all coefficients are statistically significant, the magnitudes suggest that household structure may have an impact on the labor supply decisions of household members. Switching a man from married to unmarried state reduces the probability of reemployment 
within a year by 34 percent. ${ }^{14}$ We do not observe a similar impact of marital status on the labor supply of women. Other characteristics of household composition may also have an impact on labor supply, but the effects are not statistically significant. Interestingly, the presence of young children and the elderly affect neither male nor female reemployment probabilities.

Women's labor supply is influenced by the presence and age of adult children. The existence of an adult child between 18 and 23 (or more precisely 18 and 22 and 11 months), whether a household member or not, raises the one-year reemployment rate of women by 58 percent. The necessity of paying college tuition is the likely source of a perceived need to return to the labor force and find employment more quickly. Indeed, if we run the model instead using a dummy for an adult child in college, ignoring endogeneity concerns, the reemployment rate jumps to more than 150 percent. Thus, the existence of a child aged 18 to 23 increases the intensity of search or lowers the reservation wage at which a dislocated worker will accept an offer. In contrast, a woman with an adult child over 28 is 17 percent less likely to be reemployed within a year. When adult children are over 28, mothers may find that home production as caregivers for grandchildren or elderly have a higher return than wages that can be earned through employment. In contrast, the effect of adult children on the reemployment rate of men is much smaller and statistically insignificant.

We find evidence that having a large social network speeds up the process of reemployment, which suggests that lack of information may indeed be an important factor in explaining the slow rate at which some dislocated workers find new employment. When the number of own generation relatives living within the city increases from 3 to 6, the one-year reemployment probabilities increase by 12.2 and 12.7 percent for men and women, respectively. Interestingly, the number of one's spouses own-generation relatives living in the city does not affect reemployment probabilities for men or women. By adding interaction terms, we also checked whether our social network variable mattered more for men, the less educated, or those in neighborhoods that were poorer or had more non-workers, and found no evidence of any important interaction effects.

\footnotetext{
${ }^{14}$ One should not make a causal interpretation of this coefficient since the dummy for marital status picks up both the effect of being married and a dimension of unobserved ability that may help attract a spouse in the period prior to involuntary loss of a job. If higher ability men are more likely to be married, then we would expect a positive coefficient on the marital status dummy (see Korenman and Neumark, 1991).
} 
In models (2) and (4) of Table 9, we add a dummy variable for whether or not the residents' committee provided employment referral. We observe a large positive relationship between referral services and one-year reemployment rates--27 percent for men and 29 percent for women, but these effects are not statistically significant.

\section{Endogeneity of Independent Variables}

In interpreting the results presented thus far, we may be concerned that the number of same generation relatives in a city is correlated with unobservable dimensions of ability, or that the local provision of employment referral services by residential committees is correlated with other factors affecting reemployment, such as local labor demand. To get a sense of the potential bias from making such assumptions, we regress key independent variables of interest on the variables used in the base model presented in Table 14 to see whether they are positively or negatively correlated with observable measures of ability or local labor demand. We find that years of education is not significantly related to access to public subsidies, number of own generation relatives, or spouse's own generation relatives. This provides some reassurance that our social network variables are unlikely to proxy for unobserved ability. Also, if social networks provide social insurance that makes finding a new job less urgent (which we do not believe to be the case), our estimates of the effect of social networks on reemployment probabilities will be biased downward. Given the changes in demographic structure of the Chinese family over the last two generations, it is not surprising to observe significant relationships between age and extended family size, or between household composition and extended family size.

When we examine the results for whether or not the residents' committee provides employment referral services, we find that neighborhood characteristics likely to increase the demand for labor positively predict the existence of referral services. The log average consumption per capita (a proxy for wealth), average years of schooling in the neighborhood, and share of community in more expensive private "commodity" housing are all positively associate with provision of employment referral. We also observe a positive and nearly significant coefficient on the non-working share of working age adults in the neighborhood (jiedao), suggesting that provision of services may be somewhat responsive to the needs of dislocated workers living in the neighborhood. Given that factors affecting both labor supply and demand in the community may have an impact on the decision of the residents' committee to 
provide employment referral, we control for these observable community characteristics in the estimation results presented in Table 9 when we include employment referral as a potential source of information.

\section{Conclusions}

The exit of older women from the urban labor force is one of the important features of China’s economic restructuring between 1996 and 2001. While many observers have concluded that exit of women from the labor force was driven by discrimination in layoffs and mandatory early retirement, our analyses suggests that this is not the entire story. When the demographic structure of the extended family is included in the analysis, we find that the existence of college age children may raise the probability that a displaced worker will take private sector employment, and significantly reduce the duration that women spend out of employment. These results make sense given the high return to college education and sharply rising tuitions over the past ten years. Reservation wages of workers are lowered significantly if the education of a child is at stake, and this family structure effect suggests that some decline in the labor force participation of women may be driven by labor supply decisions.

Early evidence from the 2004 and 2006 rounds of the China Health and Retirement Survey (CHNS) also suggest the possibility that early retirement and exit of women over 45 from the labor force at the height of restructuring may have been driven by relatively generous and permanent early retirement pensions. Panel data from the CHNS suggest that employment rates and labor force participation rates of women over age 45 started to increase again as of 2004. This suggests that earlier of cohorts may have been responding to very specific and generous benefits which they were able to obtain during the restructuring period, and that the earlier decline did not signal a permanent change in retirement behavior of older women.

\section{References}

Appleton, Simon, John Knight, Lina Song, and Qingjie Xia (2002). "Labor Retrenchment in China: Determinants and Consequences," China Economic Review 13: 252-275.

Bane, Mary Jo and David Ellwood (1983). “The Dynamics of Dependence: The Routes to SelfSufficiency," Office of the Assistant Secretary for Planning and Evaluation, U.S. Department of Health and Human Services.

Bellmann, Lutz, Saul Estrin, Lehmann Hartmut and Jonathan Wadsworth (1995). "The Eastern German Labor Market in Transition: Gross Flow Estimates from Panel Data,” Journal of Comparative Economics 20(2): 139-170. 
Benjamin, Dwayne, Loren Brandt and Terrence Yuen. 2003. “Employment Dynamics in State Owned Enterprises during Economic Transition," Department of Economics, University of Toronto, mimeo.

Bidani, Benu, Chorching Goh, and Christopher O’Leary (2002). Has Training Helped Employ Xiagang in China?: A Tale from Two Cities, mimeo, The World Bank.

Blanchard, Olivier, and Michael Kremer (1997). “Disorganization,” Quarterly Journal of Economics, v112, n4 (November 1997): 1091-1126.

Blank, Rebecca and Patricia Ruggles (1996). "When Do Women Use AFDC and Food Stamps: The Dynamics of Eligibility versus Participation,” Journal of Human Resources 31 (1996), 57-89.

Boeri, Tito (2000). “Transition with Labor Supply,” William Davidson Institute Working Paper No. 274.

Boeri, Tito, and Katherine Terrell (2002). “Institutional Determinants of Labor Reallocation in Transition,” Journal of Economic Perspectives 16(1): 51-76.

Calvo-Armengol, Antoni and Matthew Jackson (2004). “The Effects of Social Networks on Employment and Inequality,” American Economic Review v94, n3 (June 2004): 426-54.

Cai, Fang, Albert Park and Yaohui Zhao (2006). “The Chinese Labor Market,” in China's Great Transformation, Loren Brandt and Thomas Rawski (editors), Cambridge University Press (in press).

Cai, Fang and Yaowu Wu. 2005. The Green Book 2005, Chinese Academy of Social Sciences, Institute for Population and Labor Economics, CASS Press, Beijing.

Cameron, Stephen V. and Christopher Taber. 2004. "Estimation of Educational Borrowing Constraints Using Returns to Schooling,” in Journal of Political Economy, 112(1, pt 1): 132-182.

Carneiro, Pedro and James Heckman. 2003. “Human Capital Policy,” National Bureau of Economic Research Working Paper 9495 (February 2003).

Cao, Yuanzheng, Yingyi Qian, and Barry Weingast, "From Federalism, Chinese Style, to Privatization, Chinese Style,” Economics of Transition, Vol. 7, No. 1 (1999), pp. 103-131.

Choate, Allen C. (1998). "Local Governance in China, Part II: An Assessment of Urban Residents Committees and Municipal Community Development," The Asia Foundation Working Paper Series, No. 10, November 1998.

Christian, Michael (2004). “Educational Expenditures and Family Labor Supply,” Microeconomic and Macroeconomic Aspects of Higher Education, Ph.D. dissertation, Chapter 2, University of Michigan.

Conley, Timothy and Giorgio Topa (2002). "Socio-economic Distance and Spatial Patterns in Unemployment,” Journal of Applied Econometrics v17, n4 (July-Aug. 2002): 303-27.

Cook, Sarah (2002). “From Rice Bowl to Safety Net: Insecurity and Social Protection during China’s Transition,” Development Policy Review, 20(5): 615-635.

Davidson, Carl and Stephen Woodbury (1996). "Unemployment Insurance and Unemployment: Implications of the Reemployment Bonus Experiements,” in Advisory Council on Unemployment Compensation: Background Papers, Vol. 3. Washington, DC: ACUC, January.

Devine, Theresa J., and Nicholas M. Kiefer. 1991. Empirical Labor Economics: The Search Approach (New York and Oxford, Oxford University Press). 
Dong, Xiao-yuan, and Louis Putterman. 2001. “The Emergence of Labor Redundancy in China's State Industry: Findings from a 1980-1994 Data Panel,” Comparative Economic Studies 43(2): 111128.

Dong, Xiao-yuan, and Louis Putterman. 2003. "Soft Budget Constraints, Social Burdens, and Labor Redundancy in China’s State Industry,” Journal of Comparative Economics 31(1): 110-33.

Drury, David, and Marie W. Arneberg, eds. (2001). No More Forevers: The Chinese Labor Force in a Time of Reform, Norway: Fafo Institute for Applied Social Science.

Ellwood, David (1986). “Targetting Would-Be Long-Term Recipients of AFDC,” Office of the Assistant Secretary for Planning and Evaluation, U.S. Department of Health and Human Services.

Ge, Yanfeng (1998). Report on Urban Employment: Survey in Shenyang, Qingdao, Changsha, and Chengdu (Shenyang, Qingdao, Changsha, Chendu si chengshi chengzheng jumin jiuye zhuangkuang chouyang diaocha fenxi baogao), Beijing: UNDP.

Giles, John, Albert Park, and Fang Cai (2006a). “How Has Economic Restructuring Affected China’s Urban Workers?” The China Quarterly 185 (March 2006): 61-95.

Giles, John, Albert Park and Fang Cai (2006b). "Reemployment of Dislocated Workers in Urban China: The Roles of Information and Incentives," Journal of Comparative Economics 34(3) (September): 582-607

Giles, John, Albert Park, and Juwei Zhang (2005). “What is China’s True Unemployment Rate?,” China Economic Review, 16(2): 149-170.

Ham, John C., Jan Svejnar, and Katherine Terrell (1998). "Unemployment and the Social Safety Net During Transitions to a Market Economy: Evidence from the Czech and Slovak Republics” in American Economic Review, Vol 88 (5): 1117-1142.

Ham, John C., Jan Svejnar, and Katherine Terrell (1999). “Women’s Unemployment during Transition: Evidence from Czech and Slovak Micro-Data,” Economics of Transition 7(1): 47-78.

Hamermesh, Daniel S. (1977). Jobless Pay and Economy, The Johns Hopkins University Press, Baltimore, 1977.

Hauser, Robert M. 1993. "Trends in College Entry among Blacks, Whites and Hispanics” in Studies of Supply and Demand in Higher Education, edited by Charles Clotfelter and Michael Rothschild. Chicago: University of Chicago Press (for NBER).

Hoynes, Hilary Williamson (2000). "Local Labor Markets and Welfare Spells: Do Demand Conditions Matter?” in The Review of Economics and Statistics, 82(3): 351-368.

Hoynes, Hilary and Thomas MaCurdy (1994). “Has the Decline in Benefits Shortened Welfare Spells?” American Economic Review v84, n2 (May 1994): 43-48.

Ionnides, Yannis, and Linda Datcher Loury (2004). "Job Information Networks, Neighborhood Effects, and Inequality," Journal of Economic Literature 42: 1056-1093.

Jacoby, H. (1994). Borrowing Constraints and Progress Through School: Evidence from Peru, Review of Economics and Statistics, 76:145-58.

Jensen, Robert T. and Kaspar Richter (forthcoming). "The Health Implications of Social Security Failure: Evidence from the Russian Pension Crisis,” Journal of Public Economics.

Kalbfleisch, J.D., and R.L. Prentice (1980). The Statistical Analysis of Failure Time Data, Wiley and Sons, New York 1980. 
Katz, Lawrence F. and Bruce D. Meyer, Bruce (1990). "The Impact of the Potential Duration of Unemployment Benefits on the Duration of Unemployment,” Journal of Public Economics v41, n1 (February 1990): 45-72.

Klerman, Jacob, and Steven J. Haider (2004). "A Stock-Flow Analysis of the Welfare Caseload." Journal of Human Resources, 39(4):865-886.

Korenman, Sanders and David Neumark (1991). “Does Marriage Really Make Men More Productive?” Journal of Human Resources v26, n2 (Spring 1991): 282-307.

Lancaster, Tony (1990). The Econometric Analysis of Transition Data, Cambridge University Press.

Lardy, Nicholas R. (1998). China's Unfinished Economic Revolution, Brookings Institution Press, Washington, D.C.

Li, Guo, and Colin Lixin Xu. 2001. "State-Owned Enterprises, Labor Redundancy, and Job Creation: the Experience of the Chinese Provinces," China Economic Quarterly 1(1): 97-110.

Liu, Yuanli (2000). Health Insurance Reform in China, report to the Asian Development Bank.

Lokshin, Michael M., and Rurlan Yemtsov (2000). "Household Strategies for Coping with Poverty and Social Exclusion in Post-crisis Russia,” World Bank Research Working Paper No. 2556.

Manski, Charles F. 1993. “Income and Higher Education,” Focus 14 (Winter): 14-19.

Manski, Charles F. and David A. Wise. 1983. College Choice in America. Cambridge, MA, Harvard University Press, 1983.

Mare, Robert D. 1980. “Social Background and School Continuation Decisions,” Journal of the American Statistical Association 75(June): 295-305.

Maurer-Fazio, Margaret and James Hughes. 2002. "The Effects of Market Liberalization on the Relative Earnings of Chinese Women,” Journal of Comparative Economics v30, n4 (December 2002): 709-31.

Maurer-Fazio, Margaret, Thomas Rawski and Wei Zhang. 1999. "Inequality in the Rewards for Holding Up Half the Sky: Gender Wage Gaps in China’s Urban Labor Market, 1988-1994,” The China Journal, 41:55-88.

Meng, Xin. 2000. Labor Market Reform in China, Cambridge: Cambridge University Press.

Micklewright, John and Gyula Nagy (1994). "How Does the Hungarian Unemployment Insurance System Really Work? Economics of Transition v2, n2 (June 1994): 209-32.

Ministry of Labor (2002). China Labor and Social Security Yearbook (Beijing: Ministry of Labor).

Ministry of Labor and Social Security (2002). Selected Important Documents on Labor and Social Security in the New Period. Document Research Office of the Central Committee of the Communist Party of China, China Labor and Social Security Publishing House and Central Document Publishing House, 2002.

Montgomery, James D. (1991). "Social Networks and Labor-Market Outcomes: Toward an Economic Analysis,” American Economic Review v81, n5 (December 1991): 1407-18.

Mortenson, Dale T., and Christopher A. Pissarides. 1999. "New Developments in Models of Search in the Labor Market," in O. Ashenfelter and David Card, eds., Handbook of Labor Economics, Volume 3 (Elsevier).

Munshi, Kaivan (2003). "Networks in the Modern Economy: Mexican Migrants in the U. S. Labor Market,” Quarterly Journal of Economics v118, n2 (May 2003): 549-99. 
Murphy, David. 2002. “China - Urban Poverty - Nothing More to Lose” in The Far Eastern Economic Review, November 7, 2002.

National Statistical Bureau (2002). China Statistical Yearbook (Beijing: China Statistical Press).

Neumann, George. 1997. "Search Models and Duration Data," in Pesaran, M. Hashem, and Peter Schmidt, eds., Handbook of Applied Econometrics, V. 2: Microeconomics (Oxford and Malden, MA: Blackwell Publishers).

Lardy, Nicholas R. 1998. China's Unfinished Economic Revolution, Brookings Institution Press, Washington, D.C.

Liu, Yuanli. 2000. Health Insurance Reform in China, report to the Asian Development Bank.

National Bureau of Statistics. 2002. China Statistical Yearbook (Beijing: China Statistical Press).

Naughton, Barry. 1995. “Growing Out of the Plan: Chinese Economic Reform 1978-1993,” Cambridge University Press.

Pellizari, Michelle (2004). “Do Friends and Relatives Really Help in Getting a Good Job?” CEP Discussion Paper, No. 623 (March 2004).

Puhani, Patrick A. (2000). "Poland on the Dole: The Effect of Reducing the Unemployment Benefit Entitlement Period during Transition,” Journal of Population Economics v13, n1 (February 2000): 35-44.

Ravallion, Martin and Shaohua Chen (2005). “China’s (Uneven) Progress Against Poverty,” Journal of Development Economics (in press).

Read, Benjamin (2000). “Revitalizing the State’s Urban 'Nerve Tips',” in The China Quarterly, No. 163 (September 2000): 806-820.

Read, Benjamin (2003). State, Social Networks and Citizens in China's Urban Neighborhoods, Department of Government, Harvard University, Ph.D. Dissertation.

Reynolds, Bruce and Wenli Li. 2004. "Credit Constrained Households and Higher Education Access,” paper presented at the International Workshop on Household Credit, China Center for Economic Research, August 7, 2004.

Roberts, Dexter T. 2002. "Days of Rage: Angry Workers Hit the Streets,” in Businessweek 50 No 3777, April 8, 2002.

Rogerson, Richard, and Randall Wright. 2002. "Search-Theoretic Models of the Labor Market: A Survey,” Penn Institute.

Schultz, T.W. 1975. The value of the ability to deal with disequilibria, Journal of Economic Literature, 13:827-846.

Stephens, Melvin, Jr (2001). “The Long-Run Consumption Effects of Earnings Shocks,” Review of Economics and Statistics 83(1): 28-36.

Svejnar, Jan (1999). "Labor Markets in the Transitional Central and East European Economies," in Ahsenfelter, O., and D. Card, eds., Handbook of Labor Economics, Volume 3 (Elsevier Science), pp. 2809-2857.

Svejnar, Jan (2002). “Labor Market Flexibility in Central and Eastern Europe,” William Davidson Working Paper Number 496.

Topa, Giorgio (2001). “Social Interactions, Local Spillovers and Unemployment," Review of Economic Studies v68, n2 (April 2001): 261-95. 
Wonacott, Peter. 2002. "Laid-Off Workers Besiege Subsidiary of PetroChina - Retirement Package Battle Signals China’s Labor Woes,” in The Wall Street Journal (European Edition), March 14, 2002.

$\mathrm{Xu}$, Jianguo and Yaohui Zhao. 2000. "The Adhesion Phenomenon and State-Owned Enterprise Premium in Urban China,” Working Paper, China Center for Economic Research, Beijing University.

Yang Du and John Giles. 2006. "Economic Restructuring, Shocks to Parent Employment and the College Enrollment Decision: Evidence from Urban China,” Department of Economics, Michigan State University, mimeo.

Zhang, Juwei (2003). Urban Xiagang, Unemployment and Social Support Policies: A Literature Review of Labor Market Policies in Transitional China, Report to the World Bank. 
Figure 1

Share of Gross Value Output by Ownership Sector in Manufacturing

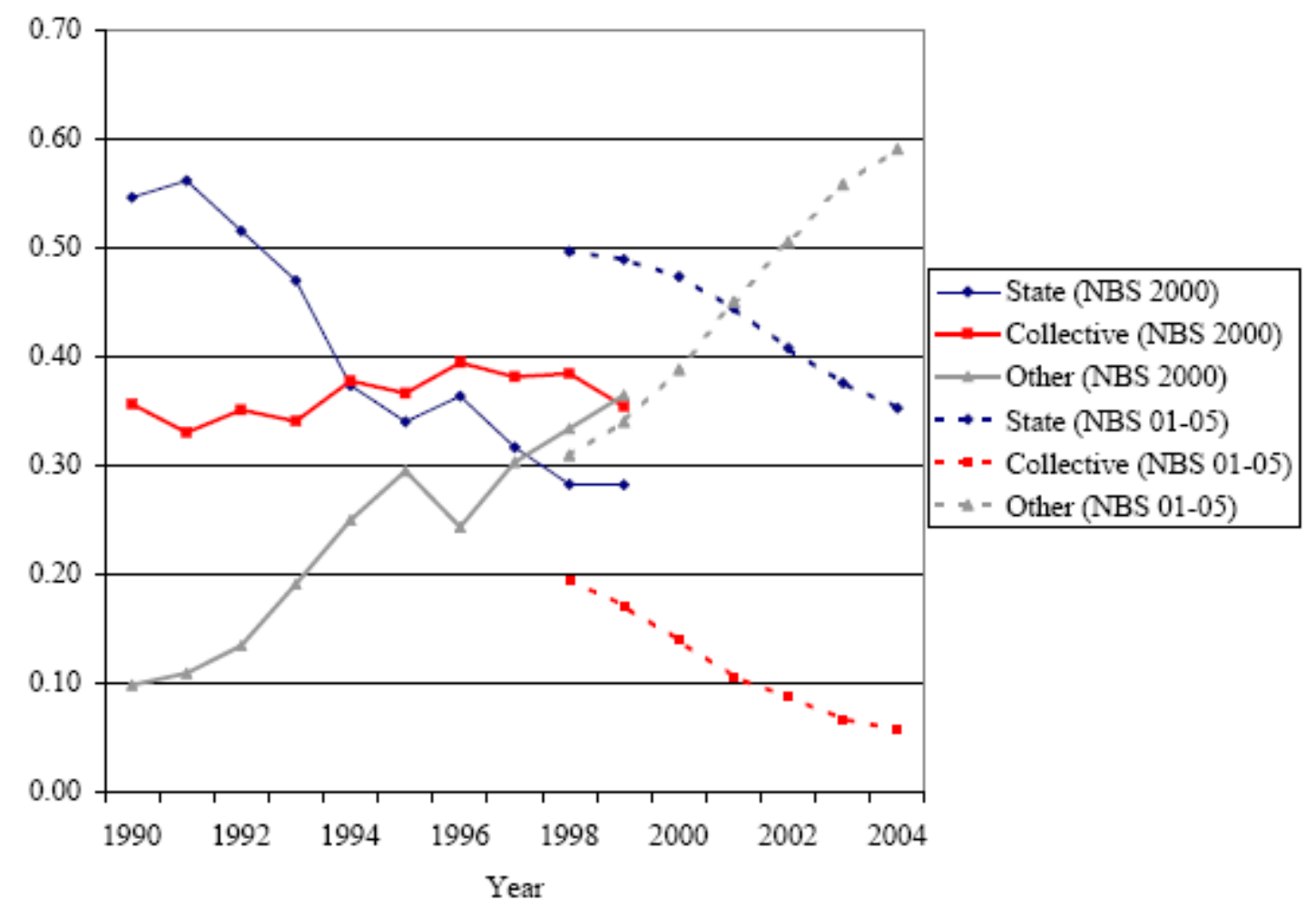

Note: The National Bureau of Statistics (NBS) introduced a new minimum scale of production for reporting with annual statistics for 2001. Since state sector firms tend to operate at a larger scale, this led to a jump in share of production with change in the data series. Still, it is evident that the SOE shares of output have continued to fall after 1991, and that the "other" sector comprising private sector, foreign invested and mixed ownership firms continued to expand. Source: NBS Statistical Yearbook (various years) 
Figure 2

Urban Employment by Ownership Sector

(in '0000s)

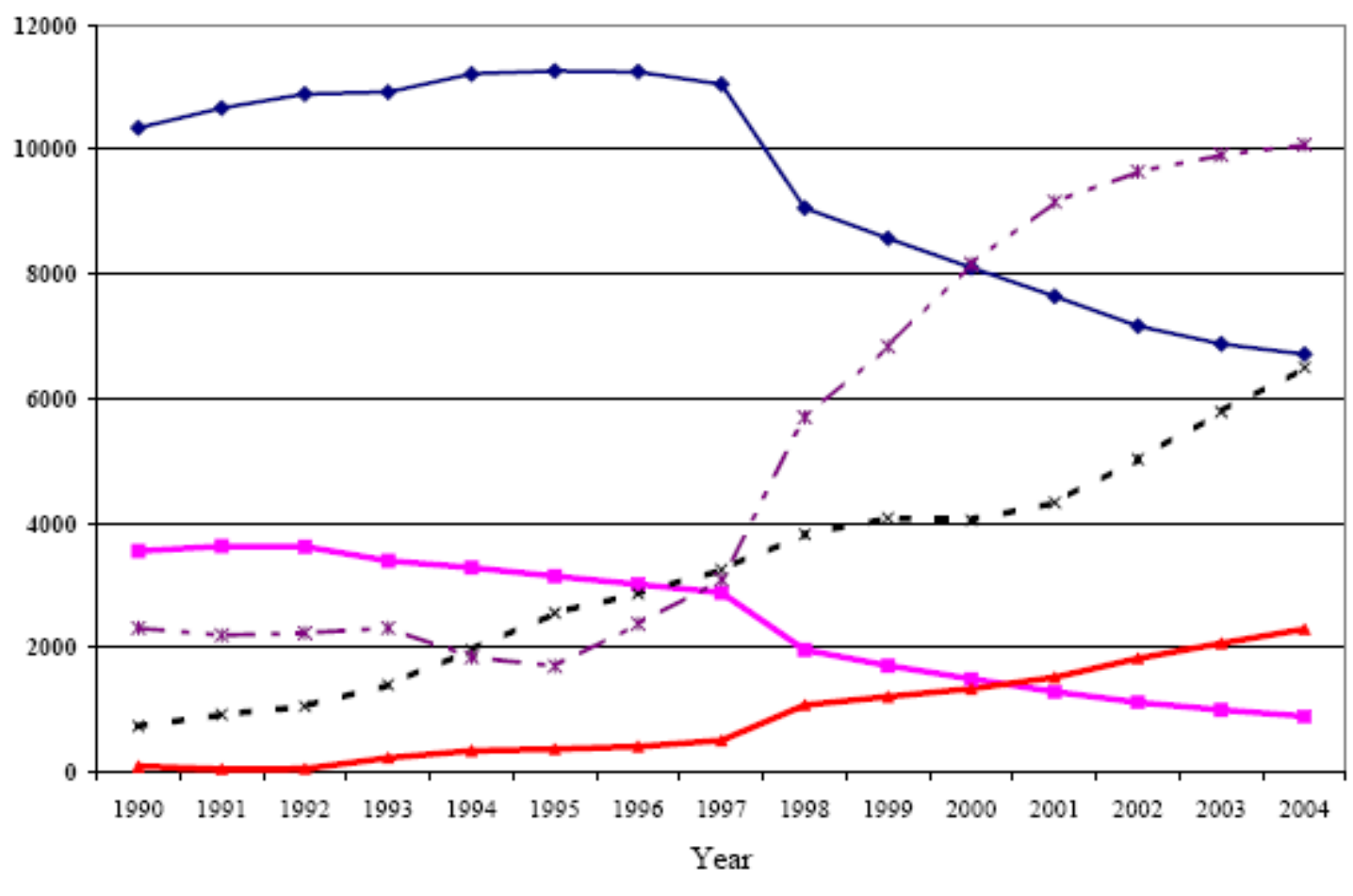

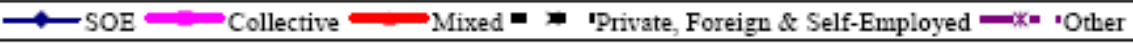


Figure 3

Distribution of Urban Employees Across Ownership Sectors

(shares of total urban labor force)

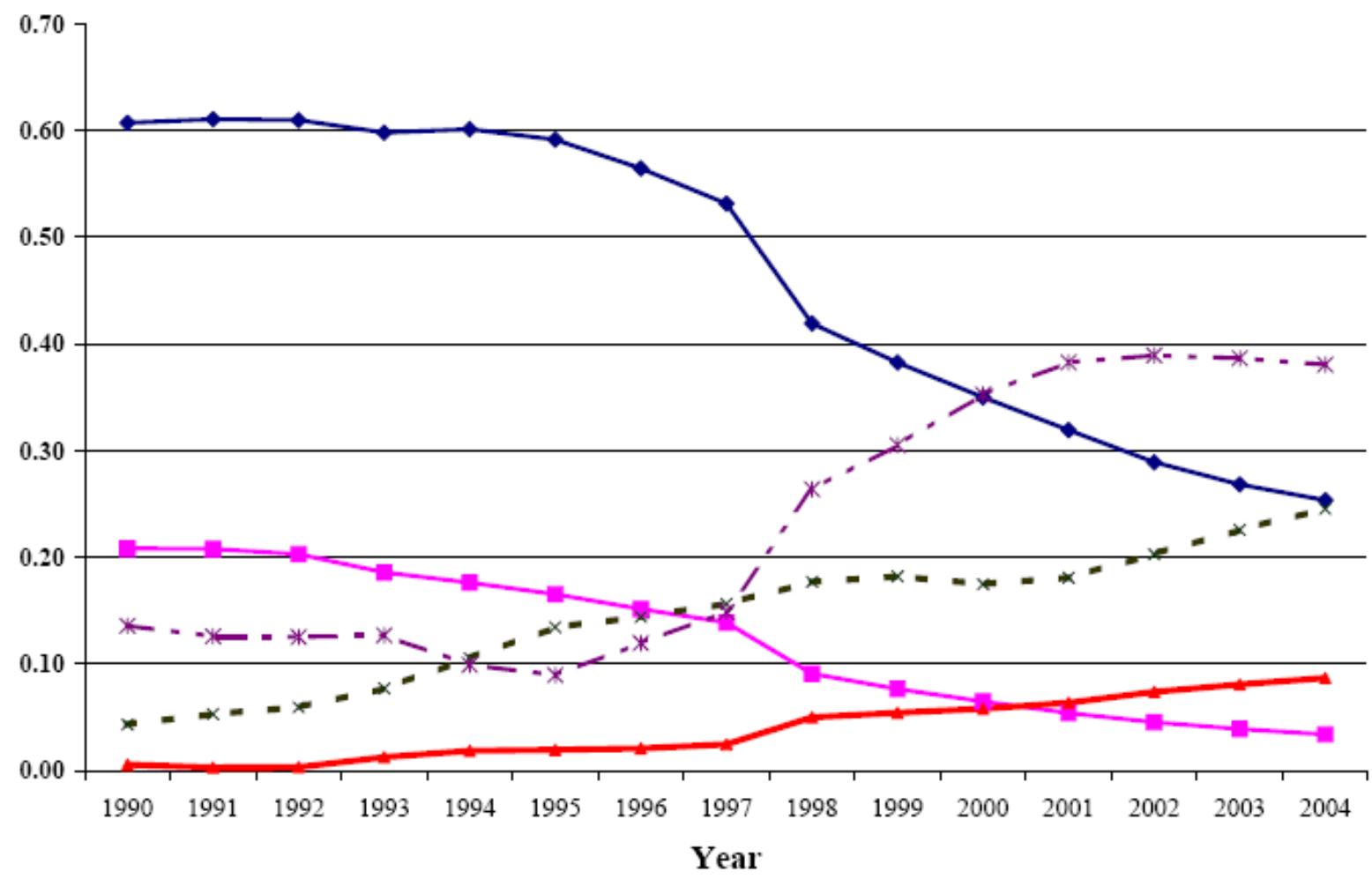

$\longrightarrow$ SOE - Collective $\longrightarrow$ 'Private, Foreign \& Self-Employed $=$ ' Other 
Figure 4

Trends in Urban Employment Status

In the CULS, 1996-2001
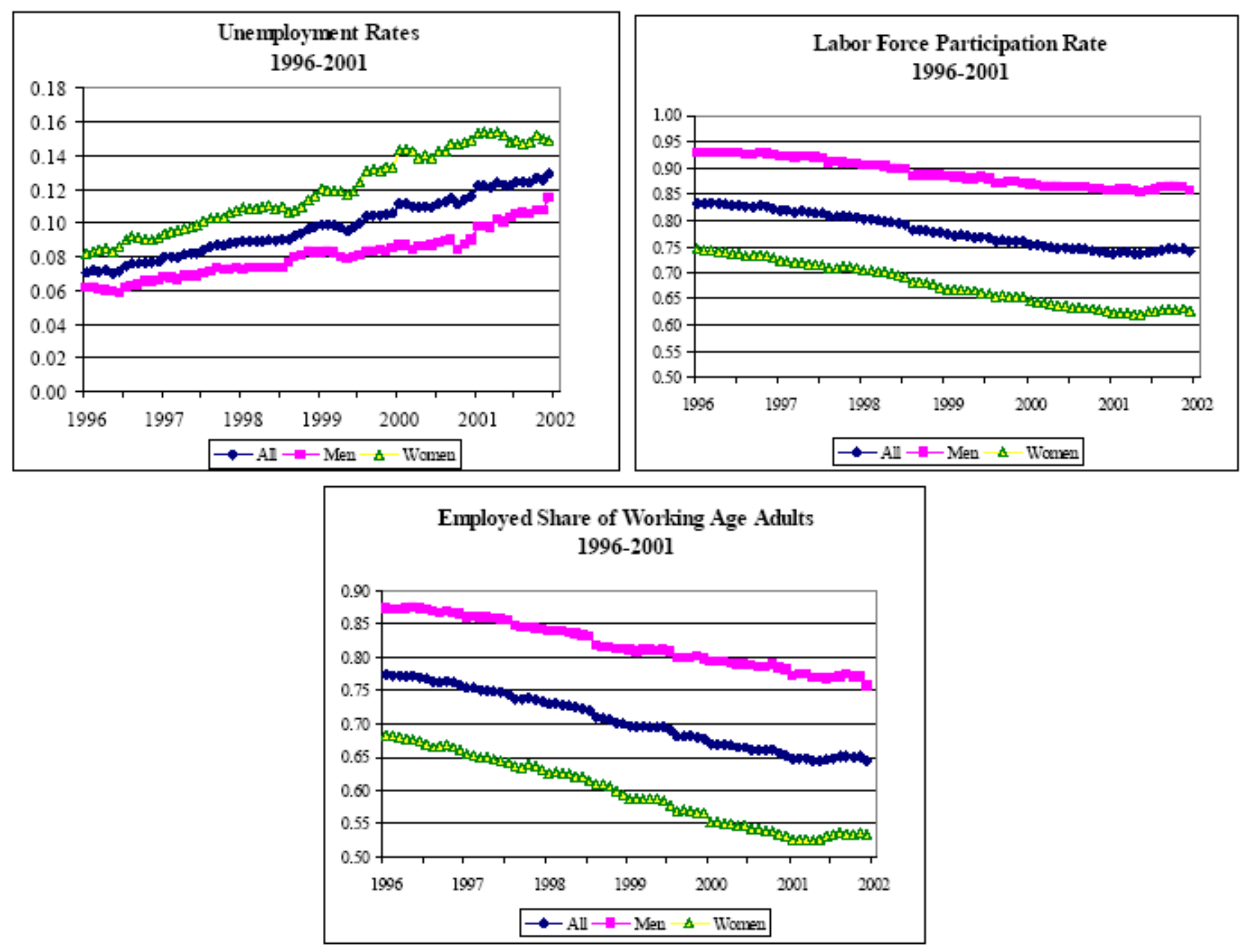

Source: China Urban Labor Survey (2001). Trends reflect respondents with contemporaneous age 16 to 60. 


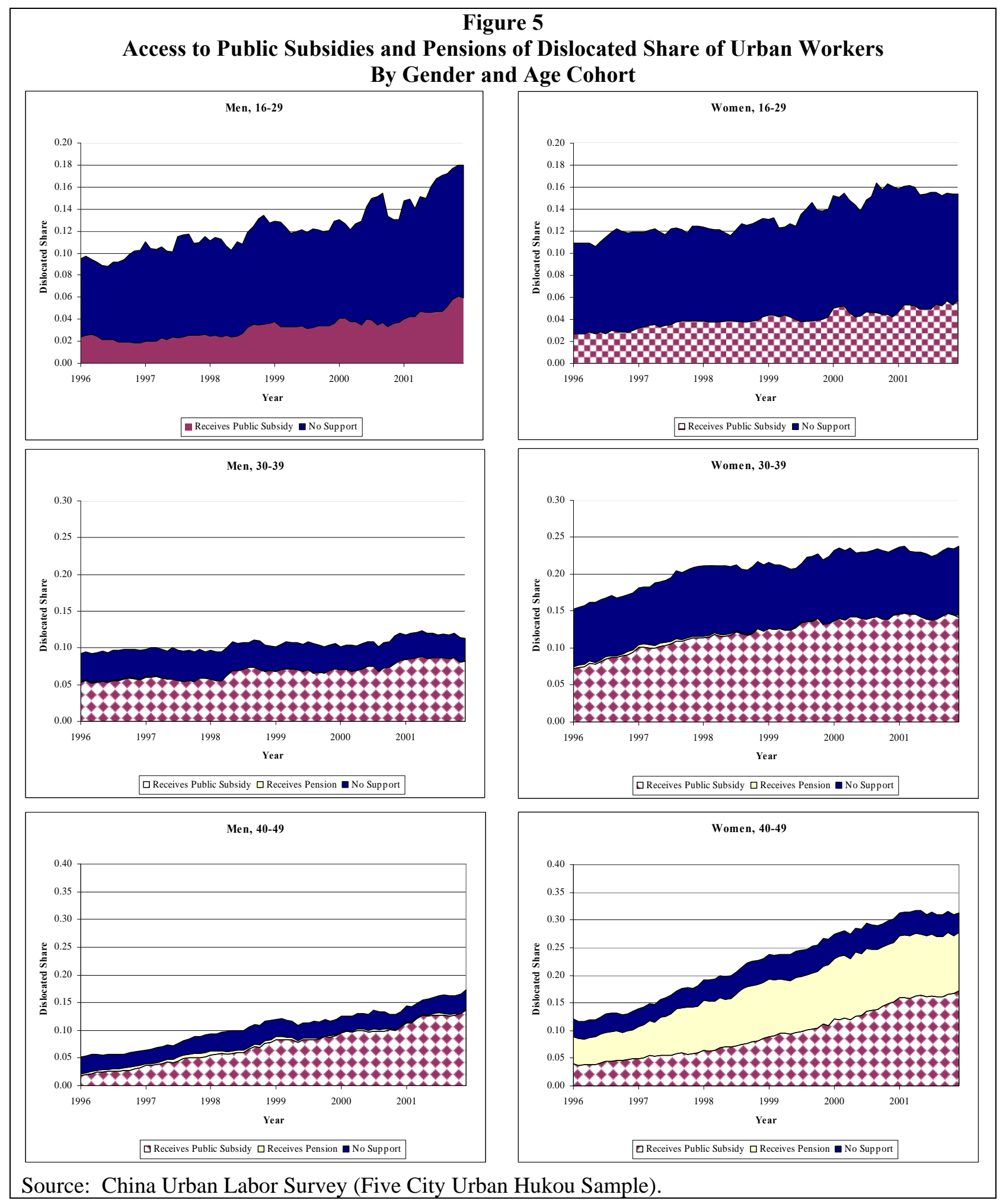




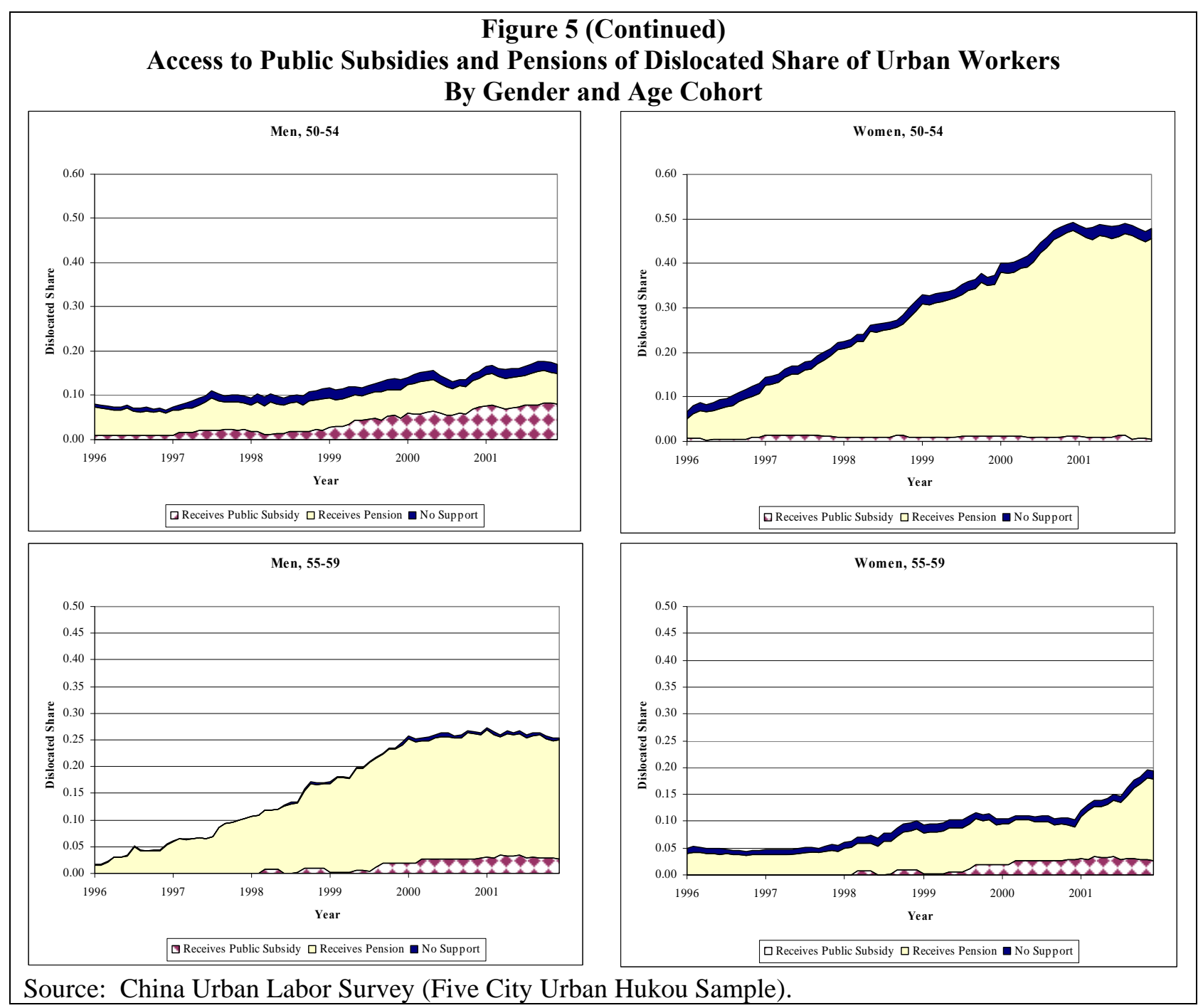


Figure 6

Duration of Non-Working Spells and Age
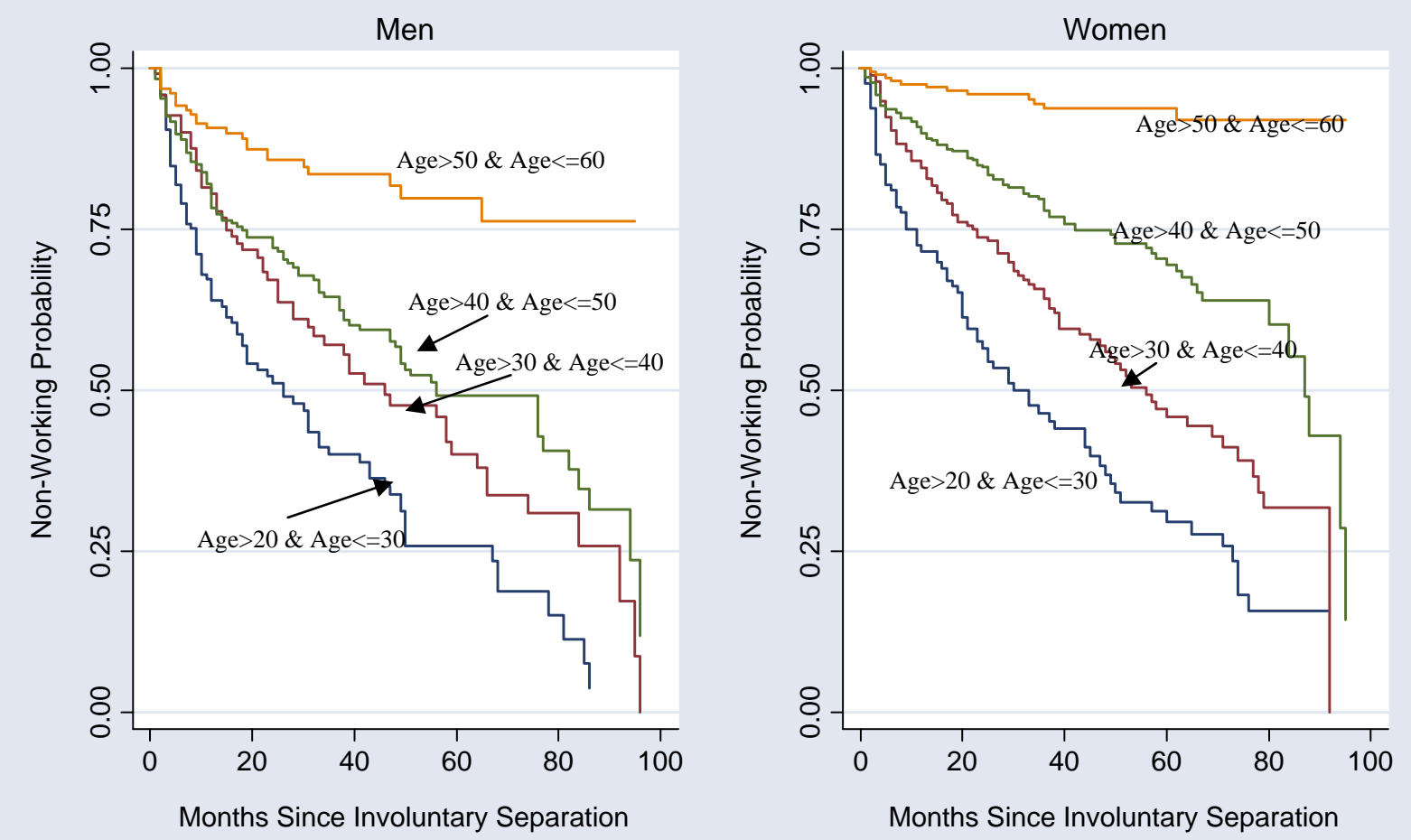

We report results for individuals who faced involuntary loss of employment and are still under the legal retirement age (55 for women and 60 for men). We show non-parametric Kaplan-Meier survival estimates.

Notes: Source data come from the China Urban Labor Survey. 
Figure 7

Duration of Non-Working Spells and Educational Attainment
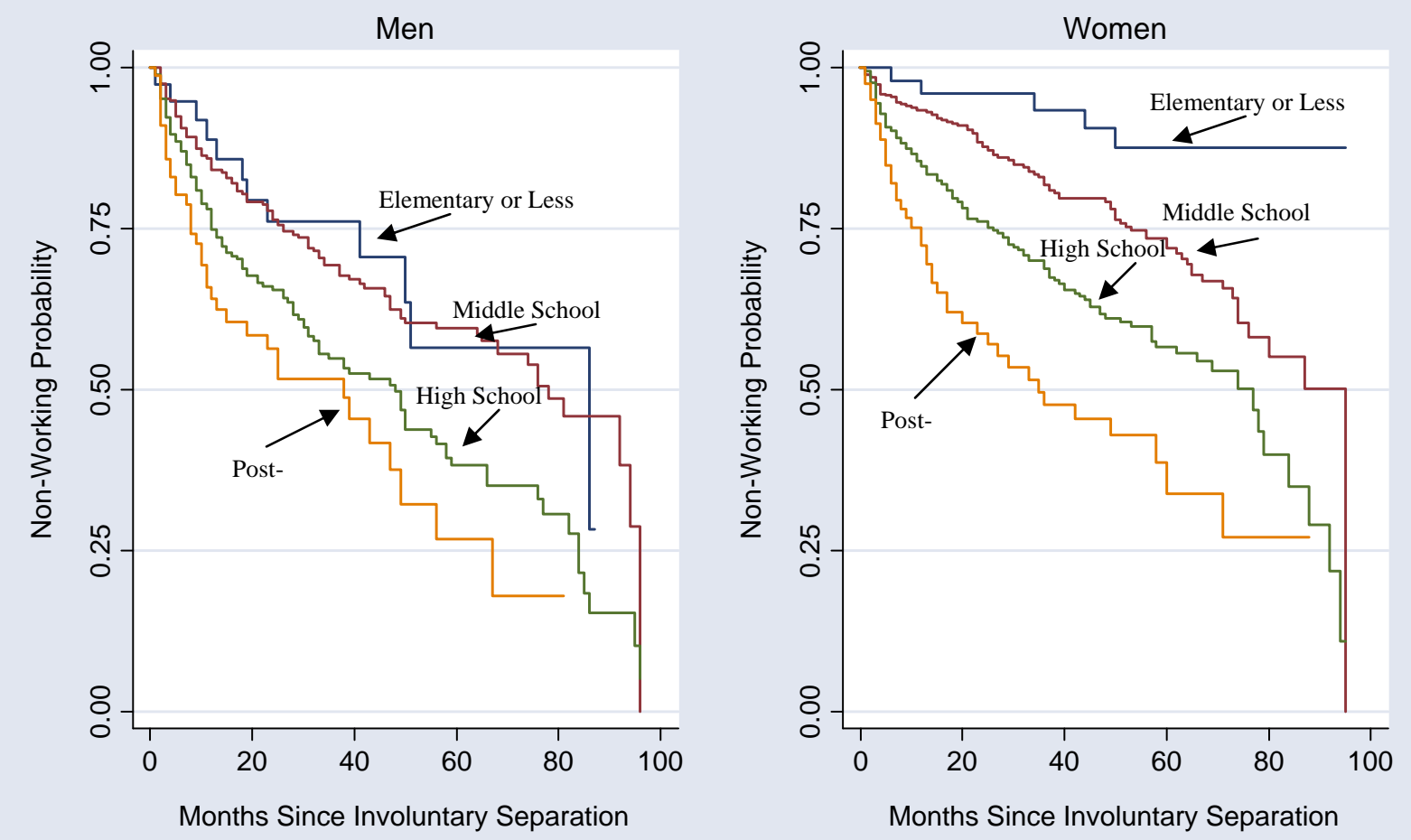

We report results for individuals who faced involuntary loss of employment and are still under the legal retirement age (55 for women and 60 for men). We show non-parametric Kaplan-Meier survival estimates.

Notes: Source data come from the China Urban Labor Survey. 


\section{Figure 8}

\section{Duration of Non-Working Spells and}

Eligibility for Formal Support
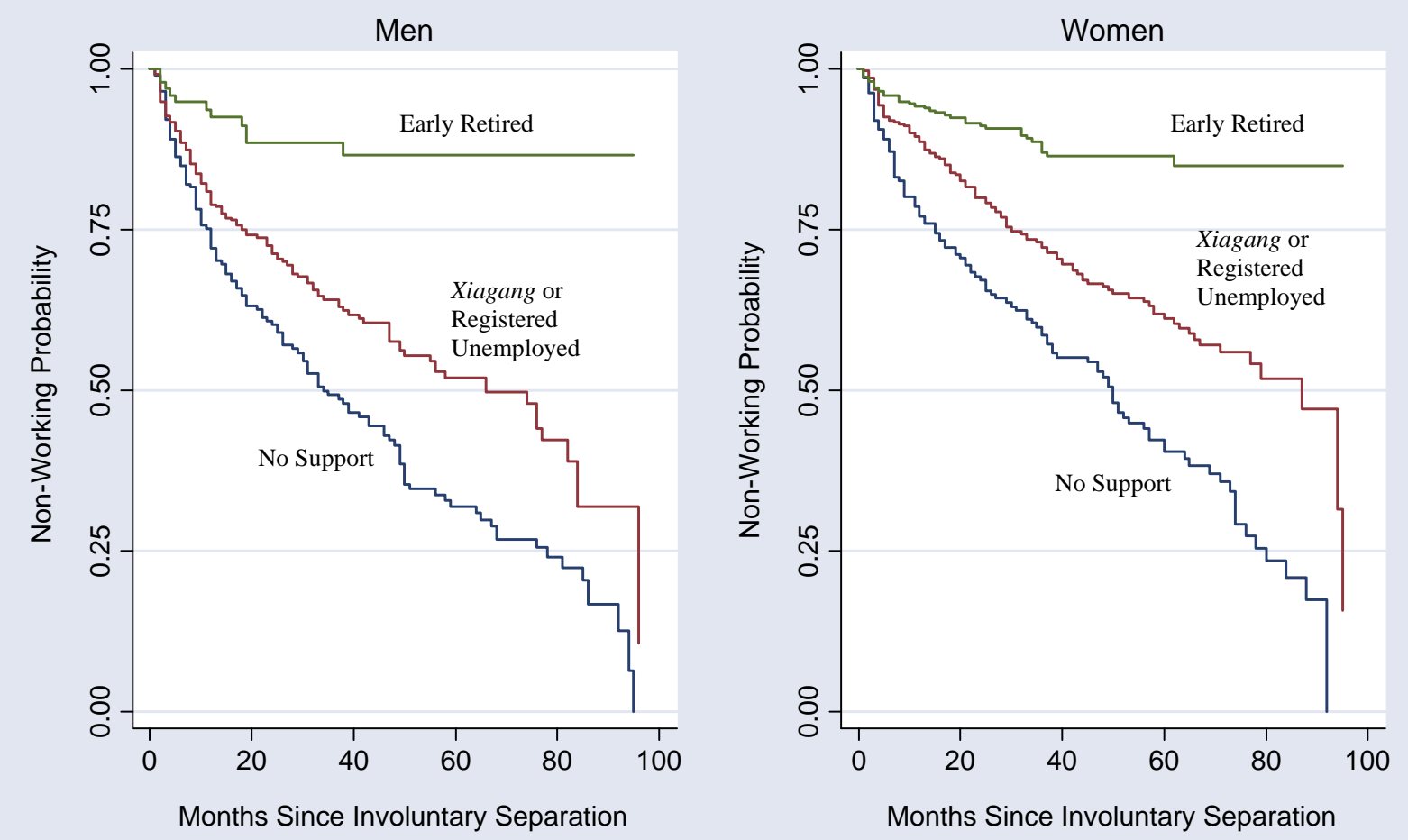

We report results for individuals who faced involuntary loss of employment and are still under the legal retirement age (55 for women and 60 for men). We show non-parametric Kaplan-Meier survival estimates.

Notes: Source data come from the China Urban Labor Survey. 
Figure 9

Duration of Non-Working Spells and Number of

Own-Generation Relatives Living in the City
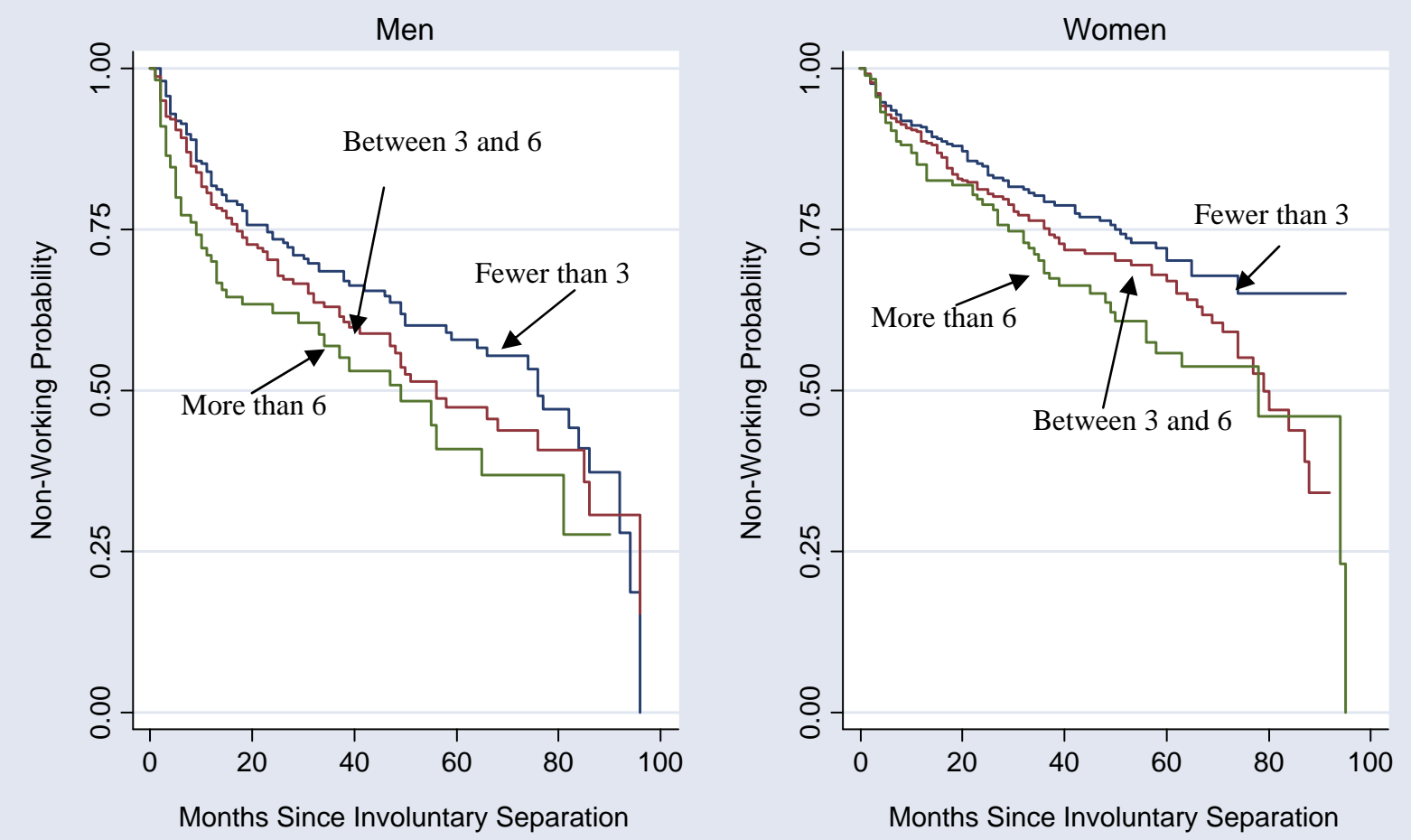

We report results for individuals who faced involuntary loss of employment and are still under the legal retirement age (55 for women and 60 for men). We show non-parametric Kaplan-Meier survival estimates.

Notes: Source data come from the China Urban Labor Survey. 
Table 1

Urban Employment Indicators, 1995 to 2004

\begin{tabular}{lccccc}
\hline & $\begin{array}{c}\text { Laid off } \\
\text { (xiagang) } \\
\text { workers } \\
\text { (million) }\end{array}$ & $\begin{array}{c}\text { Laid off } \\
\text { (xiagang) SOE } \\
\text { workers } \\
\text { (million) }\end{array}$ & $\begin{array}{c}\text { Number } \\
\text { of SOE } \\
\text { workers } \\
\text { (million) }\end{array}$ & $\begin{array}{c}\text { Registered } \\
\text { unemployed } \\
\text { workers } \\
\text { (million) }\end{array}$ & $\begin{array}{c}\text { Registered } \\
\text { unemployment } \\
\text { rate } \\
\text { (percent) }\end{array}$ \\
\hline 1995 & 5.64 & 3.68 & 112.61 & 5.20 & 2.9 \\
1996 & 8.15 & 5.42 & 112.44 & 5.53 & 3.0 \\
1997 & 6.34 & 6.34 & 110.44 & 5.77 & 3.1 \\
1998 & 7.39 & 5.62 & 90.58 & 5.71 & 3.1 \\
1999 & 7.81 & 6.19 & 85.72 & 5.75 & 3.1 \\
2000 & 5.12 & 4.45 & 81.02 & 5.95 & 3.1 \\
2001 & 2.83 & 2.34 & 76.40 & 6.81 & 3.6 \\
2002 & 2.11 & 1.62 & 71.63 & 7.70 & 4.0 \\
2003 & & & & & \\
2004 & & & & & \\
Total & 45.39 & 35.66 & & & \\
\hline
\end{tabular}

Source: China Labor Statistical Year Book, 1996-2004; Annual Report on Labor and Social Security by MOLSS and NBS. 
Table 2

Estimates of China's Unemployment Rate

\begin{tabular}{|c|c|c|c|c|c|c|c|c|c|c|c|c|c|c|}
\hline & & & 1993 & 1994 & 1995 & 1996 & 1997 & 1998 & 1999 & 2000 & 2001 & 2002 & 2003 & 2004 \\
\hline 1 & XZ\&KX & census/population survey & & & $\begin{array}{l}7.6- \\
7.7\end{array}$ & & & & & 11.5 & & & & \\
\hline 2 & XZ\&KX & 6 province survey & & & $\begin{array}{l}9.5- \\
9.6\end{array}$ & & & & 11.6 & & & 12.4 & & \\
\hline 3 & AKX & adjusted official data & & & & & & & 8.2 & & & & & \\
\hline 4 & XZ & adjusted official data & 3.2 & 3.6 & 4.3 & 4.8 & 5.5 & 4.5 & 6.3 & 8.1 & & & & \\
\hline 5 & $\mathrm{KX}$ & adjusted official data & 3.2 & 3.6 & 4.4 & 4.9 & 5.7 & 6.9 & 7.1 & 7.1 & 6.6 & 6.2 & & \\
\hline 7 & $\mathrm{Hu}^{*}$ & adjusted official data & & & & & $>5-7.0$ & $>8.0$ & & & & & & \\
\hline 8 & $\mathrm{UN}^{*}$ & adjusted official data & & & & & & & $\begin{array}{l}7.9- \\
8.5\end{array}$ & & & & & \\
\hline 9 & Lee* & adjusted official data & & & & & & & $8-9$ & & & & & \\
\hline 6 & $\mathrm{KR}^{*}$ & source unclear & & & & & 14.0 & & & & & & & \\
\hline 5 & $\mathrm{XZ}$ & $\begin{array}{l}\text { author's estimates from } \\
(1),(2) \text {, and (4) }\end{array}$ & 7.1 & 8.6 & 7.7 & 7.3 & 9.2 & 10.8 & 12.5 & 11.5 & & & & \\
\hline 10 & $\mathrm{KX}$ & $\begin{array}{l}\text { Authors' estimates from } \\
\text { (1), (2), and (5) }\end{array}$ & 5.9 & 6.8 & 7.7 & 8.5 & 9.5 & 10.1 & 10.8 & 11.5 & 12.6 & 13.1 & & \\
\hline 11 & GPZ & $\begin{array}{l}\text { Authors' estimates using } \\
\text { national } 2000 \text { census and } \\
\text { five-city survey }\end{array}$ & & & & 6.8 & 7.7 & 8.5 & 9.0 & 10.0 & 10.8 & 11.1 & & \\
\hline $11 \mathrm{a}$ & GPZ & $\begin{array}{l}\text { Estimates including rural } \\
\text { migrants living in cities }\end{array}$ & & & & 4.5 & 5.0 & 5.6 & 5.9 & 6.5 & 7.0 & 7.3 & & \\
\hline 12 & MOLSS02 & $\begin{array}{l}66 \text { - City survey based } \\
\text { on ILO standards }\end{array}$ & & & & & & & & & & 8.75 & & \\
\hline $12 \mathrm{a}$ & MOLSS02 & $\begin{array}{l}\text { (12) Estimates including } \\
\text { rural migrants }\end{array}$ & & & & & & & & & & 8.51 & & \\
\hline 13 & IPLE04 & $\begin{array}{c}14 \text { - City survey based } \\
\text { on ILO standards }\end{array}$ & & & & & & & & & & & & 9.9 \\
\hline \multicolumn{7}{|c|}{$\begin{array}{l}\text { *cited in Solinger (2002) } \\
\text { XZ=Xue and Zhong (2003) } \\
\text { KX=Knight and Xue (2004) } \\
\text { AKX=Appleton, Knight, Song, and Xia (2002) } \\
\text { Hu=Hu Angang, cited by Rawski (2001) } \\
\text { UNDP=United Nations Development Program (1999) }\end{array}$} & \multicolumn{8}{|c|}{$\begin{array}{l}\text { Lee=Lee (2000) } \\
\text { KR=Kernen and Rocca (1999) } \\
\text { GPZ=Giles, Park and Zhang (2005) } \\
\text { MOLSS02=MOLSS 66-City Survey (2002) } \\
\text { IPLE04=CASS-IPLE 14 City Survey (2004) }\end{array}$} \\
\hline
\end{tabular}


Table 3

Poverty Rates in Cities Focused on

Resource Extraction

\begin{tabular}{lccc} 
& Total & Outside Northeast & $\begin{array}{c}\text { Three Northeastern } \\
\text { Provinces }\end{array}$ \\
\hline Total & 5.12 & 4.51 & 8.34 \\
& $(620)$ & $(530)$ & $(90)$ \\
$\begin{array}{l}\text { Cities Not Based on } \\
\text { Resource Extraction }\end{array}$ & 4.52 & 4.18 & 6.72 \\
$\begin{array}{l}\text { Cities w/ Industry-Based } \\
\text { on Resource Extraction } \\
\text { (Non-Exhausted) }\end{array}$ & $(497)$ & $(437)$ & $(60)$ \\
$\begin{array}{l}\text { Cites Previously Based on } \\
\text { Resource Extraction with }\end{array}$ & $(109)$ & 6.67 & 10.35 \\
Exhausted Resource & 10.92 & $(84)$ & 16.66 \\
& $(14)$ & 6.53 & $(5)$ \\
\hline
\end{tabular}

From Cai and $\mathrm{Wu}$ (2005). Numbers in parentheses reflect number of cities in sample. 


\section{Table 4}

\section{Labor Force Characteristics of Urban Residents by Demographic Group Across Years and Surveys}

\begin{tabular}{|c|c|c|c|c|}
\hline & \multicolumn{2}{|c|}{$\begin{array}{c}2002 \\
\text { (MOLSS 66-City) }\end{array}$} & \multicolumn{2}{|c|}{$\begin{array}{c}2004 \\
\text { (SP 14-City) }\end{array}$} \\
\hline & $\begin{array}{c}\text { Unemployment } \\
\text { Rate } \\
(\%)\end{array}$ & $\begin{array}{c}\text { Labor Force } \\
\text { Participation } \\
(\%) \\
\end{array}$ & $\begin{array}{c}\text { Unemployment } \\
\text { Rate } \\
(\%) \\
\end{array}$ & $\begin{array}{c}\text { Labor Force } \\
\text { Participation } \\
(\%)\end{array}$ \\
\hline Full Sample & 8.8 & 59.0 & 9.9 & 59.0 \\
\hline $\begin{array}{l}\text { By Demographic } \\
\text { Group: }\end{array}$ & & & & \\
\hline Men (16-65) & 7.9 & 68.5 & 8.4 & 68.9 \\
\hline$<30$ & 11.5 & 55.6 & 12.4 & 48.2 \\
\hline$>=30 \&<40$ & 7.2 & 87.2 & 6.5 & 91.2 \\
\hline$>=40 \&<45$ & 8.1 & 83.1 & 7.9 & 90.8 \\
\hline$>=45 \&<50$ & 6.4 & 81.2 & 9.0 & 84.9 \\
\hline$>=50 \&<55$ & 6.2 & 68.1 & 7.1 & 68.0 \\
\hline$>=55 \&<60$ & 5.6 & 44.6 & 10.8 & 44.2 \\
\hline$>=60 \&<65$ & 3.0 & 14.4 & 5.1 & 13.1 \\
\hline Women (16-65) & 9.4 & 49.8 & 12.0 & 49.4 \\
\hline$<30$ & 10.8 & 51.2 & 9.5 & 45.1 \\
\hline$>=30 \&<40$ & 9.6 & 72.1 & 11.7 & 76.4 \\
\hline$>=40 \&<45$ & 9.6 & 66.3 & 13.4 & 72.0 \\
\hline$>=45 \&<50$ & 8.0 & 51.1 & 17.2 & 55.5 \\
\hline$>=50 \&<55$ & 6.6 & 25.9 & 7.0 & 24.2 \\
\hline$>=55 \&<60$ & 4.3 & 10.8 & 14.7 & 9.8 \\
\hline$>=60 \&<65$ & 2.2 & 4.9 & 0 & 4.4 \\
\hline
\end{tabular}


Table 5

Laid-Off, Unemployed and Retired Worker Access to Benefits and Employment Status 2002 MOLSS 66-City Survey

\begin{tabular}{|c|c|c|c|c|c|c|c|c|c|}
\hline & \multicolumn{3}{|c|}{ Laid-Off (Xiagang) Workers } & \multicolumn{3}{|c|}{ Registered Unemployed } & \multicolumn{3}{|c|}{ Retired } \\
\hline & $\begin{array}{c}\text { Xiagang } \\
\text { Rate } \\
(\%) \\
\end{array}$ & $\begin{array}{c}\text { Xiagang } \\
\text { w/Benefits } \\
(\%)\end{array}$ & $\begin{array}{c}\text { Xiagang \& } \\
\text { Working } \\
(\%)\end{array}$ & $\begin{array}{c}\text { Registered } \\
\text { Unemp } \\
\text { Rate (\%) }\end{array}$ & $\begin{array}{c}\text { Reg Un } \\
\text { w/Benefits } \\
(\%)\end{array}$ & $\begin{array}{c}\text { Reg Un \& } \\
\text { Working } \\
(\%)\end{array}$ & $\begin{array}{c}\text { Retired } \\
\text { Rate } \\
(\%)\end{array}$ & $\begin{array}{c}\text { Retired } \\
\text { w/Pensions } \\
(\%)\end{array}$ & $\begin{array}{c}\text { Retired \& } \\
\text { Working } \\
(\%)\end{array}$ \\
\hline Full Sample & 8.8 & 27.9 & 53.7 & 7.6 & 42.2 & 28.3 & 15.5 & 96.8 & 13.9 \\
\hline $\begin{array}{l}\text { By Demographic } \\
\text { Group: }\end{array}$ & & & & & & & & & \\
\hline Men (16-65) & 9.5 & 27.3 & 59.3 & 6.1 & 42.6 & 34.2 & 11.0 & 95.6 & 17.3 \\
\hline$<30$ & 2.7 & 16.8 & 70.7 & 4.0 & 18.8 & 22.9 & 0.3 & 60.8 & 60.0 \\
\hline$>=30 \&<40$ & 12.7 & 22.4 & 64.3 & 7.9 & 45.7 & 38.8 & 0.5 & 74.6 & 48.6 \\
\hline$>=40 \&<45$ & 16.9 & 28.0 & 58.1 & 9.5 & 47.0 & 38.1 & 1.6 & 75.0 & 36.4 \\
\hline$>=45 \&<50$ & 15.2 & 30.4 & 58.7 & 8.4 & 47.2 & 36.9 & 3.1 & 85.5 & 36.3 \\
\hline$>=50 \&<55$ & 11.5 & 36.5 & 48.8 & 5.2 & 53.6 & 28.4 & 13.8 & 93.9 & 23.3 \\
\hline$>=55 \&<60$ & 5.2 & 39.2 & 37.9 & 2.5 & 58.3 & 21.2 & 43.2 & 98.0 & 15.0 \\
\hline$>=60 \&<65$ & 0.6 & 44.2 & 42.9 & 0.2 & 41.7 & 8.3 & 90.7 & 98.8 & 10.8 \\
\hline Women (16-65) & 8.0 & 28.5 & 47.0 & 6.3 & 38.2 & 23.5 & 19.98 & 97.5 & 11.9 \\
\hline$<30$ & 2.6 & 19.9 & 56.9 & 4.5 & 19.0 & 15.3 & 0.2 & 60.3 & 60.0 \\
\hline$>=30 \&<40$ & 12.6 & 25.5 & 49.8 & 10.4 & 41.6 & 25.3 & 0.5 & 79.1 & 41.8 \\
\hline$>=40 \&<45$ & 18.3 & 30.7 & 45.2 & 11.1 & 47.5 & 26.9 & 2.6 & 90.4 & 28.1 \\
\hline$>=45 \&<50$ & 12.9 & 33.7 & 41.7 & 7.1 & 41.0 & 25.0 & 20.5 & 96.4 & 20.9 \\
\hline$>=50 \&<55$ & 1.5 & 34.8 & 35.0 & 0.9 & 17.1 & 14.3 & 62.1 & 98.6 & 13.1 \\
\hline$>=55 \&<60$ & 0.5 & 31.9 & 43.0 & 0.4 & 5.0 & 5.0 & 72.8 & 98.8 & 7.2 \\
\hline$>=60 \&<65$ & 0.2 & 21.0 & 14.9 & 0.1 & 0.0 & 14.3 & 77.8 & 98.4 & 3.8 \\
\hline
\end{tabular}


Table 6

Laid-Off, Unemployed and Retired Worker Access to Benefits and Employment Status 2004 Social Protection 14-City Survey




Table 7

\section{Sources of Formal Support During Non-Working Spells Of Involuntarily Out-Of-Work Adults}

\begin{tabular}{|c|c|c|c|c|c|}
\hline \multirow[b]{2}{*}{ Sector } & \multirow{2}{*}{$\begin{array}{l}\text { Total Non- } \\
\text { Working } \\
\text { Spells }\end{array}$} & \multicolumn{4}{|c|}{ Share (\%) with Potential Access to Different Safety Nets } \\
\hline & & No Benefits & $\begin{array}{c}\text { Registered } \\
\text { Unemployed }\end{array}$ & Xiagang & $\begin{array}{c}\text { Early } \\
\text { Retired }\end{array}$ \\
\hline $\begin{array}{l}\text { Government_or_Party } \\
\text { State Owned or Controlled }\end{array}$ & 33 & 51.5 & 0.0 & 6.1 & 42.4 \\
\hline Enterprises & 547 & 23.8 & 4.0 & 33.1 & 39.1 \\
\hline Collective_Enterprise & 315 & 29.8 & 2.9 & 38.4 & 28.9 \\
\hline Foreign Invested Enterprise & 27 & 48.1 & 11.1 & 29.6 & 11.1 \\
\hline Private or Individual & 163 & 62.6 & 4.9 & 23.3 & 9.2 \\
\hline Other & 17 & 35.3 & 11.8 & 23.5 & 29.4 \\
\hline Missing Response to Sector & 5 & 40.0 & 0.0 & 20.0 & 40.0 \\
\hline Total & 1107 & 32.9 & 4.0 & 32.1 & 31.1 \\
\hline
\end{tabular}

Women

\begin{tabular}{lccccc}
\hline & $\begin{array}{c}\text { Total Non- } \\
\text { Working }\end{array}$ & \multicolumn{4}{c}{ Share (\%) with Potential Access to Different Safety Nets } \\
Spells & No Benefits & $\begin{array}{c}\text { Registered } \\
\text { Unemployed }\end{array}$ & Xiagang & $\begin{array}{c}\text { Early } \\
\text { Retired }\end{array}$ \\
\hline Sector & & & & & \\
Government or Party & 36 & 22.2 & 2.8 & 2.8 & 72.2 \\
State Owned Enterprise & 844 & 17.1 & 2.3 & 20.0 & 60.7 \\
State Controlled Enterprise & 189 & 18.0 & 3.2 & 22.8 & 56.1 \\
State Owned or Controlled & & & & & \\
Enterprises & 1033 & 17.2 & 2.4 & 20.5 & 59.8 \\
Collective Enterprise & 705 & 27.5 & 1.0 & 23.4 & 48.1 \\
Foreign_Invested & 25 & 88.0 & 4.0 & 8.0 & 0.0 \\
Private or Individual & 205 & 62.0 & 2.4 & 21.0 & 14.6 \\
Other & 32 & 46.9 & 3.1 & 18.8 & 31.3 \\
Missing Response to Sector & 49 & 83.7 & 0.0 & 0.0 & 16.3 \\
& & & & & \\
Total & 2,085 & 28.1 & 1.9 & 20.6 & 49.4 \\
& & & & & \\
\hline
\end{tabular}

Source: China Urban Labor Survey, 2001. 
Table 8

The Impact of Education, Age, Employment Background and Labor Demand on Re-Employment Rates

Sample: Working Age Adults Involuntarily Leaving Previous Employment

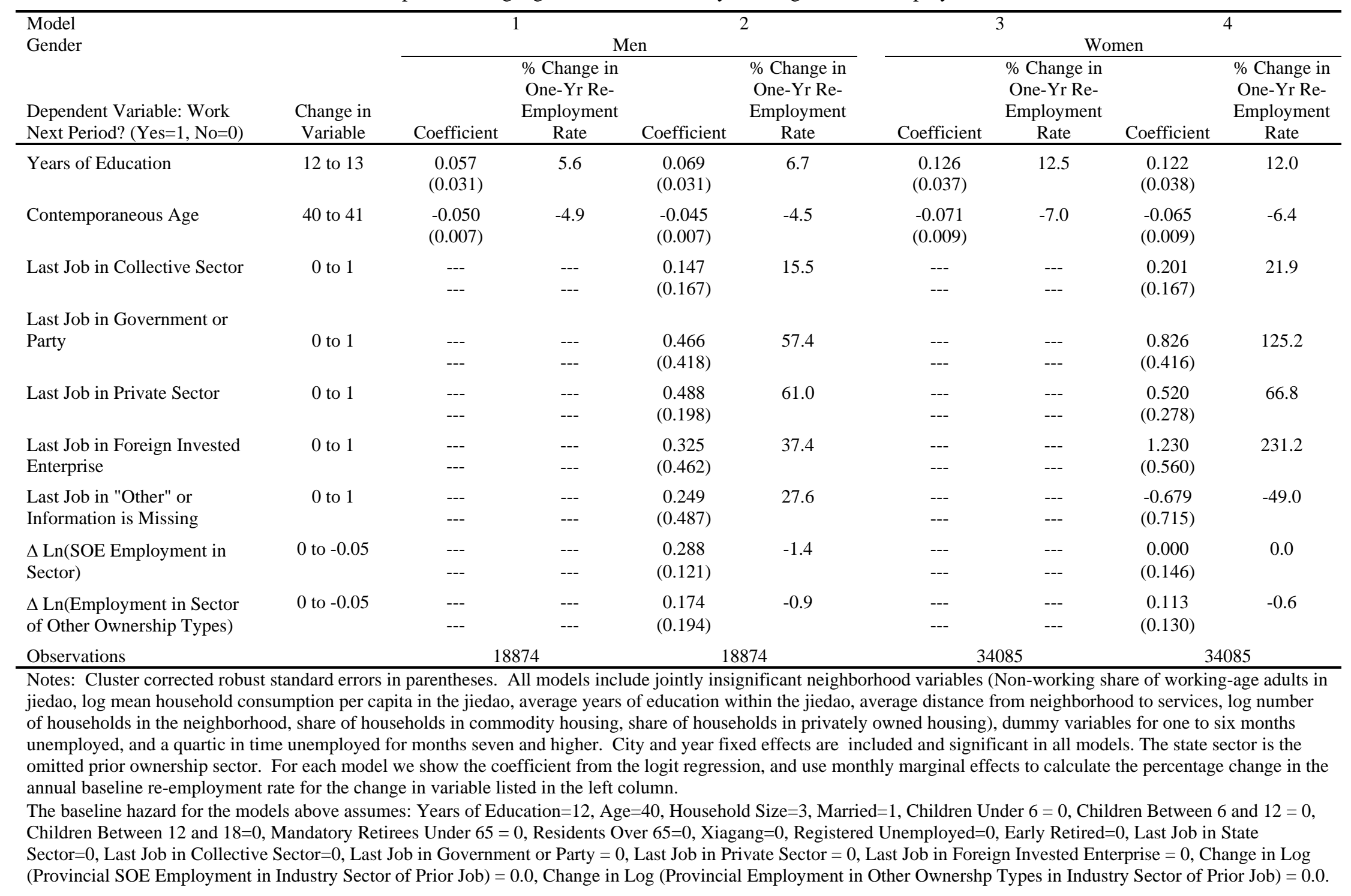


Table 9

The Impact of Access to Benefits and Family Demographics on Re-Employment Rates

Sample: Working Age Men and Women Involuntarily Leaving Previous Employment from January 1993-October 2001

\begin{tabular}{|c|c|c|c|c|c|c|c|c|c|}
\hline \multirow{2}{*}{$\begin{array}{l}\text { Model } \\
\text { Gender } \\
\text { Dependent Variable: Work Next } \\
\text { Period? (Yes=1, No=0) }\end{array}$} & \multirow[b]{2}{*}{$\begin{array}{l}\text { Change in } \\
\text { Variable }\end{array}$} & \multicolumn{2}{|c|}{1} & \multicolumn{2}{|c|}{2} & \multicolumn{2}{|c|}{3} & \multicolumn{2}{|c|}{4} \\
\hline & & Coefficient & $\begin{array}{l}\text { \% Change in } \\
\text { One-Yr Re- } \\
\text { Employment } \\
\text { Rate }\end{array}$ & Coefficient & $\begin{array}{l}\text { \% Change in } \\
\text { One-Yr Re- } \\
\text { Employment } \\
\text { Rate }\end{array}$ & Coefficient & $\begin{array}{l}\text { \% Change in } \\
\text { One-Yr Re- } \\
\text { Employment } \\
\text { Rate } \\
\end{array}$ & Coefficient & $\begin{array}{l}\text { \% Change in } \\
\text { One-Yr Re- } \\
\text { Employment } \\
\text { Rate }\end{array}$ \\
\hline Access to Public Subsidies & 0 to 1 & $\begin{array}{l}-0.433 \\
(0.136)\end{array}$ & -34.4 & $\begin{array}{l}-0.430 \\
(0.136)\end{array}$ & -34.3 & $\begin{array}{l}-0.193 \\
(0.194)\end{array}$ & -17.4 & $\begin{array}{l}-0.178 \\
(0.194)\end{array}$ & -16.1 \\
\hline Early Retirement Pension & 0 to 1 & $\begin{array}{l}-1.480 \\
(0.400)\end{array}$ & -76.7 & $\begin{array}{l}-1.470 \\
(0.400)\end{array}$ & -76.4 & $\begin{array}{l}-0.933 \\
(0.305)\end{array}$ & -60.3 & $\begin{array}{l}-0.907 \\
(0.311)\end{array}$ & -59.4 \\
\hline Household Size & 3 to 4 & $\begin{array}{l}-0.034 \\
(0.122)\end{array}$ & -3.2 & $\begin{array}{l}-0.038 \\
(0.120)\end{array}$ & -3.7 & $\begin{array}{l}-0.124 \\
(0.196)\end{array}$ & -12.2 & $\begin{array}{l}-0.120 \\
(0.200)\end{array}$ & -11.9 \\
\hline Adult Child $(18<=$ Age $<23)$ ? & 0 to 1 & $\begin{array}{c}0.178 \\
(0.228)\end{array}$ & 18.7 & $\begin{array}{c}0.183 \\
(0.230)\end{array}$ & 19.4 & $\begin{array}{c}0.467 \\
(0.201)\end{array}$ & 58.1 & $\begin{array}{c}0.478 \\
(0.202)\end{array}$ & 60.0 \\
\hline Adult Child $(23<=$ Age $<28)$ ? & 0 to 1 & $\begin{array}{l}-0.103 \\
(0.278)\end{array}$ & -9.5 & $\begin{array}{l}-0.078 \\
(0.278)\end{array}$ & -7.3 & $\begin{array}{l}-0.165 \\
(0.249)\end{array}$ & -15.0 & $\begin{array}{l}-0.150 \\
(0.253)\end{array}$ & -13.8 \\
\hline $\begin{array}{l}\text { Number of Adult Children Over } \\
28\end{array}$ & 0 to 1 & $\begin{array}{c}0.029 \\
(0.106)\end{array}$ & 2.8 & $\begin{array}{l}0.027 \\
(0.104)\end{array}$ & 2.7 & $\begin{array}{l}-0.169 \\
(0.088)\end{array}$ & -16.7 & $\begin{array}{l}-0.174 \\
(0.089)\end{array}$ & -17.2 \\
\hline $\begin{array}{l}\text { Own Generation Relatives } \\
\text { Living in Same City }\end{array}$ & 3 to 6 & $\begin{array}{c}0.042 \\
(0.021)\end{array}$ & 12.2 & $\begin{array}{c}0.042 \\
(0.022)\end{array}$ & 12.4 & $\begin{array}{c}0.043 \\
(0.020)\end{array}$ & 12.7 & $\begin{array}{c}0.046 \\
(0.020)\end{array}$ & 13.6 \\
\hline $\begin{array}{l}\text { Spouse's Own Generation } \\
\text { Relatives Living in Same City }\end{array}$ & 3 to 6 & $\begin{array}{c}0.005 \\
(0.029)\end{array}$ & 1.5 & $\begin{array}{c}0.008 \\
(0.029)\end{array}$ & 2.2 & $\begin{array}{c}0.002 \\
(0.025)\end{array}$ & 0.7 & $\begin{array}{l}-0.001 \\
(0.025)\end{array}$ & -0.2 \\
\hline $\begin{array}{l}\text { Neighborhood Committee } \\
\text { Provides Employment Referral }\end{array}$ & 0 to 1 & --- & -- & $\begin{array}{c}0.250 \\
(0.230)\end{array}$ & 27.3 & --- & -- & $\begin{array}{c}0.260 \\
(0.207)\end{array}$ & 29.2 \\
\hline $\begin{array}{l}\text { Baseline One-Year Re- } \\
\text { Employment Rate }\end{array}$ & & \multicolumn{2}{|c|}{0.415} & \multicolumn{2}{|c|}{0.339} & \multicolumn{2}{|c|}{0.190} & \multicolumn{2}{|c|}{0.153} \\
\hline Monthly Observations & & \multicolumn{2}{|c|}{18874} & \multicolumn{2}{|c|}{18874} & \multicolumn{2}{|c|}{34085} & \multicolumn{2}{|c|}{34085} \\
\hline $\begin{array}{l}\text { Notes: Cluster corrected robust st } \\
\text { shown in Table A1. Further, all n } \\
\text { City and year fixed effects are in } \\
\text { effects to calculate the percentage } \\
\text { The baseline hazard for the model } \\
=0 \text {, Children Between } 12 \text { and } 18= \\
\text { Sector=0, Last Job in Collective S } \\
\text { Log (Provincial SOE Employmen } \\
\text { Job) = 0, Respondent's Own Gene } \\
\text { variables are evaluated at mean va }\end{array}$ & $\begin{array}{l}\text { dard errors } \\
\text { dels include } \\
\text { ided and sig } \\
\text { hange in the } \\
\text { above assum } \\
\text { Mandatory } \\
\text { tor=0, Last } \\
\text { n Industry S } \\
\text { tion Relativ } \\
\text { tes. }\end{array}$ & $\begin{array}{l}\text { ficant in all } m \\
\text { anual baselin } \\
\text { : Years of Ec } \\
\text { etirees Unde } \\
\text { b in Governn } \\
\text { tor of Prior J } \\
=3 \text {, Spouse }\end{array}$ & $\begin{array}{l}\text { All models incl } \\
\text { s for one to six } \\
\text { dels.For each n } \\
\text { re-employment } \\
\text { Ication }=12, \text { Ag } \\
65=0 \text {, Residen } \\
\text { ent or Party }=0 \\
\text { b) }=0 \text {, Change } \\
\text { Own Generatic }\end{array}$ & $\begin{array}{l}\text { months unen } \\
\text { odel we sho } \\
\text { rate for the c } \\
=40 \text {, Househ } \\
\text { s Over } 65=0 \\
\text { Last Job in } 1 \\
\text { n Log (Provi } \\
\text { n Relatives }\end{array}$ & $\begin{array}{l}\text { gressors showı } \\
\text { loyed, and a qu } \\
\text { the coefficient } \\
\text { nge in variabl } \\
\text { d Size=3, Mar } \\
\text { Kiagang=0, Re } \\
\text { vate Sector = } \\
\text { ial Employme } \\
\text { Neighborhoo }\end{array}$ & $\begin{array}{l}\text { from the logit } \\
\text { listed in the l } \\
\text { ied=1, Childr } \\
\text { istered Unem } \\
\text {, Last Job in } 1 \\
\text { t in Other Ov } \\
\text { Has Employ }\end{array}$ & $\begin{array}{l}\text { empioyed ror } \\
\text { egression, and } \\
\text { it column. } \\
\text { Under } 6=0 \text {, } \\
\text { loyed }=0 \text {, Early } \\
\text { reign Investec } \\
\text { iershp Types i } \\
\text { ient Referral S }\end{array}$ & $\begin{array}{l}\text { and these reg } \\
\text { nonths seven } \\
\text { use monthly r } \\
\text { Children Bety } \\
\text { Retired=0, L } \\
\text { Enterprise = } \\
\text { Industry Sec } \\
\text { ervice=0, and }\end{array}$ & $\begin{array}{l}\text { essors are } \\
\text { nd higher. } \\
\text { arginal } \\
\text { en } 6 \text { and } 12 \\
\text { t Job in State } \\
\text { Change in } \\
\text { or of Prior } \\
\text { eighborhood }\end{array}$ \\
\hline
\end{tabular}




\section{RECENT WORKING PAPERS FROM THE}

\section{CENTER FOR RETIREMENT RESEARCH AT BOSTON COLLEGE}

Sources of Support for Pension Reform: A Cross-National Perspective Michelle Dion and Andrew Roberts, January 2009

The Long-Term Effect of the Divorce Revolution: Health, Wealth, and Labor Supply

Kristin Mammen, December 2008

The Response of Household Saving to the Large Shock of German Reunification Nicola Fuchs-Schündeln, November 2008

A Parsimonious Choquet Model of Subjective Life Expectancy

Alexander Ludwig and Alexander Zimper, November 2008

Risky Pensions and Household Saving Over the Life Cycle

David A. Love and Paul A. Smith, November 2008

Identifying Local Differences in Retirement Patterns

Leora Friedberg, Michael Owyang, and Anthony Webb, November 2008

What Effect Do Time Constraints Have on the Age of Retirement? Leora Friedberg, Wei Sun, Anthony Webb, November 2008

Dual-Eligible Medicaid Spending: Are We on the Flat of the Curve?

Melissa A. Boyle, Joanna N. Lahey, and Margaret E. Czervionke, November 2008

Public Long-Term Care Insurance and the Housing and Living Arrangements of the Elderly: Evidence from Medicare Home Health Benefits

Gary V. Engelhardt and Nadia Greenhalgh-Stanley, November 2008

The Impact of Changing Earnings Volatility on Retirement Wealth Austin Nichols and Melissa M. Favreault, November 2008

The Housing Bubble and Retirement Security

Alicia H. Munnell and Mauricio Soto, with the assistance of Jean-Pierre Aubry, November 2008

All working papers are available on the Center for Retirement Research website (http://www.bc.edu/crr) and can be requested by e-mail (crr@bc.edu) or phone (617-552-1762). 